\title{
Cold plasma technology: advanced and sustainable approach for wastewater treatment
}

\author{
Prateek Gururani ${ }^{1} \cdot$ Pooja Bhatnagar ${ }^{2} \cdot$ Bhawna Bisht $^{2,3} \cdot$ Vinod Kumar $^{2,4}$ (I) Naveen Chandra Joshi ${ }^{5} \cdot$ \\ Mahipal Singh $\operatorname{Tomar}^{6} \cdot$ Beena Pathak $^{7}$
}

Received: 28 July 2021 / Accepted: 22 September 2021 / Published online: 7 October 2021

(C) The Author(s), under exclusive licence to Springer-Verlag GmbH Germany, part of Springer Nature 2021

\begin{abstract}
Cold plasma has been a potent energy-efficient and eco-friendly advanced oxidation technology which has gained attention in recent decades as a non-thermal approach in diverse forms of applications. This review highlights a comprehensive account of the implementation of this technology in the field of wastewater treatment to resolve certain issues regarding the degradation of numerous aqueous pollutants and water-borne pathogenic microorganisms including viruses up to a significant level. The paper addresses plasma chemistry sources and mechanisms on wastewater treatment and impact on various physical, chemical, and biological characteristics of treated water. Furthermore, studies have revealed that this emerging technology is effective in inactivating SARS-CoV-2 or coronavirus, which serves as a transmission channel for this lethal virus in wastewater. Despite these benefits, the development of cold plasma as a wastewater treatment technique is still hampered by a lack of information like capital investment, proficient application, liveability, and operating cost, thus necessitating additional research for its booming commercialization, as this can be an emerging approach to solving water crises and meeting the demand for fresh or potable water resources.
\end{abstract}

Keywords Cold plasma $\cdot$ Wastewater $\cdot$ SARS-CoV-2

\section{Introduction}

In recent decades, the presence of numerous kinds of novel contaminants has been recognized and their potential environmental ramifications have been drawn attention. New source contaminants which require new treatment and means of detection are called "emerging." They are classified based on the probable and apprehensible risk to the environment and human health. The inflating anthropogenic activities results in the continuous release of emerging contaminants into the natural environment (Fatima and Kumar 2020). They originate either from industries or may come from agricultural, municipal (domestic), laboratory, or hospital wastewater, which damage human, terrestrial and aquatic ecosystems (Shah

Responsible Editor: Philippe Garrigues

Bhawna Bisht

bhawnabisht494@gmail.com

$\triangle$ Vinod Kumar

kumarvinod.ls@geu.ac.in

1 Department of Biotechnology, Graphic Era (Deemed to be University), Dehradun 248002, India

2 Department of Life Sciences, Graphic Era (Deemed to be University), Dehradun 248002, India

3 Department of Post-Harvest Process and Food Engineering, G. B. Pant University of Agriculture and Technology, Pantnagar, Uttarakhand 263145, India
4 Peoples' Friendship University of Russia (RUDN University), Moscow, Russian Federation 117198

5 Material Science \& Nanotechnology Laboratory, Research \& Development, Uttaranchal University, Dehradun, Uttarakhand 248007, India

6 Department of Food Process Engineering, National Institute of Technology, Rourkela 76900I, India

7 Department of Food Science and Technology, G. B. Pant University of Agriculture and Technology, Pantnagar, Uttarakhand 263145, India 
et al. 2020). Accommodating over 44 million people who rely on surface water, the World Health Organisation's analysis indicates that 785 million people have insufficient drinking water supplies. In addition, about two billion people around the world use a drinking water source contaminated by faecal matter, which can cause around 485000 fatalities per year from diarrhoea (WHO 2019). Moreover, the reports on SARS-CoV-2 transmission or coronavirus transmission via wastewater provides an urgency for implementation of an adequate wastewater treatment technology (Rimoldi et al. 2020). Wastewaters can be regarded as untapped resources and, as water and energy resources are lacking worldwide, the focus has switched to remediation of these substances to preserve earthly life. For this reason, it is crucial that new environmentally friendly and highly efficient wastewater treatment methods and clean water generation continue to be the main priority (Oturan and Aaron 2014).

Using sophisticated analytical methods, wastewater is regarded as an efficient resource for balancing water demand on a variety of scales, particularly in arid, semi-arid, metropolitan areas, for drinking water supplies, agriculture, and other activities. Presently, scientists are pushed forward to establish several conventional methods like chemical, biological and physical methods of wastewater treatment. But all these methods have numerous disadvantages such as non-reactive chemical residues and inorganic solids (Zeghioud et al. 2020). In addition, these methods are inefficient against some organic pollutants that have a very little concentration and are not biodegradable easily (Iervolino et al. 2019). For instance, techniques like flocculation, coagulation, ion exchange etc. exhibit high consumption of energy and reagents, low selectivity with high investment and operational cost (LaureanoAnzaldo et al. 2020). Moreover, incineration and thermal oxidation require high running costs and emit various dioxins and other pollutants into the environment. Likewise, biological methods are also related to several flaws like unrestricted breakdown of products, low biodegradability of some pollutants such as dyes and also requires maintenance and management of microorganisms (Crini and Lichtfouse 2019).

To overcome these limitations of conventional methods, technologists are more concentrated towards establishment of modern oxidation processes like cold plasma technology (Wang et al. 2015; Duan et al. 2015), photo-Fenton techniques (Ameta and Ameta, 2018), photocatalysis (Vaiano et al. 2017; Vaiano and Iervolino 2018), ozonation (Saeid et al. 2018), electrochemical reactions (Garcia-Segura et al. 2018), irradiation technology (Bisht et al. 2021; Pricaz and Uta 2015) or a combination of these for treating wastewater followed by microbial inactivation. All such techniques undergo the process of mineralization, causing decomposition of various organic pollutants, i.e. changing of compounds to inorganic intermediates, water and carbon dioxide. It has been proved that these methods possess the potential of degrading toxic pollutants and recalcitrant materials (García et al. 2017). However, a complete oxidation process is a prior necessity for treatment of wastewater that cannot be achieved by techniques like ultrasonication, UV/ozone, photocatalysis etc. (Thirumdas et al. 2015). As the challenges of wastewater treatment are expanding, cold plasma technology, therefore provides a more viable and emerging advanced oxidation processes (AOPs) option for the solution (Zeghioud et al. 2020).

Cold plasma technology is one type of non-thermal technique which generates several reactive species like $\mathrm{O}, \mathrm{OH}$, $\mathrm{H}_{2} \mathrm{O}_{2}, \mathrm{H}, \mathrm{O}_{3}$, and $\mathrm{HO}_{2}$ which interact with molecules of water, simultaneously emitting light and producing shockwaves. In particular, non-thermal plasma offers the advantage of $\mathrm{OH}$ radicals' generation and added reactive species being independent on the inclusion of UV lamps and costly chemicals (Iervolino et al. 2019). Furthermore, it is simple, eco-friendly, economical and easily-to-use technology at room temperature and atmospheric pressure which has the capability of eliminating various toxic components found in wastewater including microorganisms (Zeghioud et al. 2020; Li et al. 2020).

Several traditional approaches and advanced oxidation processes (AOPs) experimented in the recent past. This review article is to provide a deep imminent of cold plasma technology encompassing removal efficiencies of numerous toxic aqueous pollutants including microorganisms and viruses for treating wastewater. This article also emphasizes its effect on the physical, chemical and biological characteristics of treated wastewater and long-term application prospects.

\section{Wastewater and its different sources}

Water (chemically defined, $\mathrm{H}_{2} \mathrm{O}$ ) is the most liberal and precious compound covering $70 \%$ of the earth's surface existing in dynamic equilibrium between gas and liquid phase at average pressure and temperature. It is an odourless and tasteless liquid reflecting a slight tint of blue colour at room temperature and acts as a dissolving medium for many substances, hence also termed as universal solvent. It is a most commonly known natural compound enduring in all three states, i.e. solid, liquid, and gas (Hossain 2015).

Nevertheless, from the last few years, problems related to water pollution or generation of wastewater in surplus amounts are rising at a very rapid rate due to enhancement in population, industrial activities and economy (LaureanoAnzaldo et al. 2020). The term "wastewater" can be defined as "any water whose biological, physical or chemical composition has been altered due to direct discharge of various pollutants into water bodies either from domestic or industrial sources thus making it unfit for portable and other purposes" (Amoatey and Bani 2011; Laureano-Anzaldo et al. 2020). Figure 1 shows the various sources responsible for generation of wastewater. 
Fig. 1 Different sources responsible for generation of wastewater

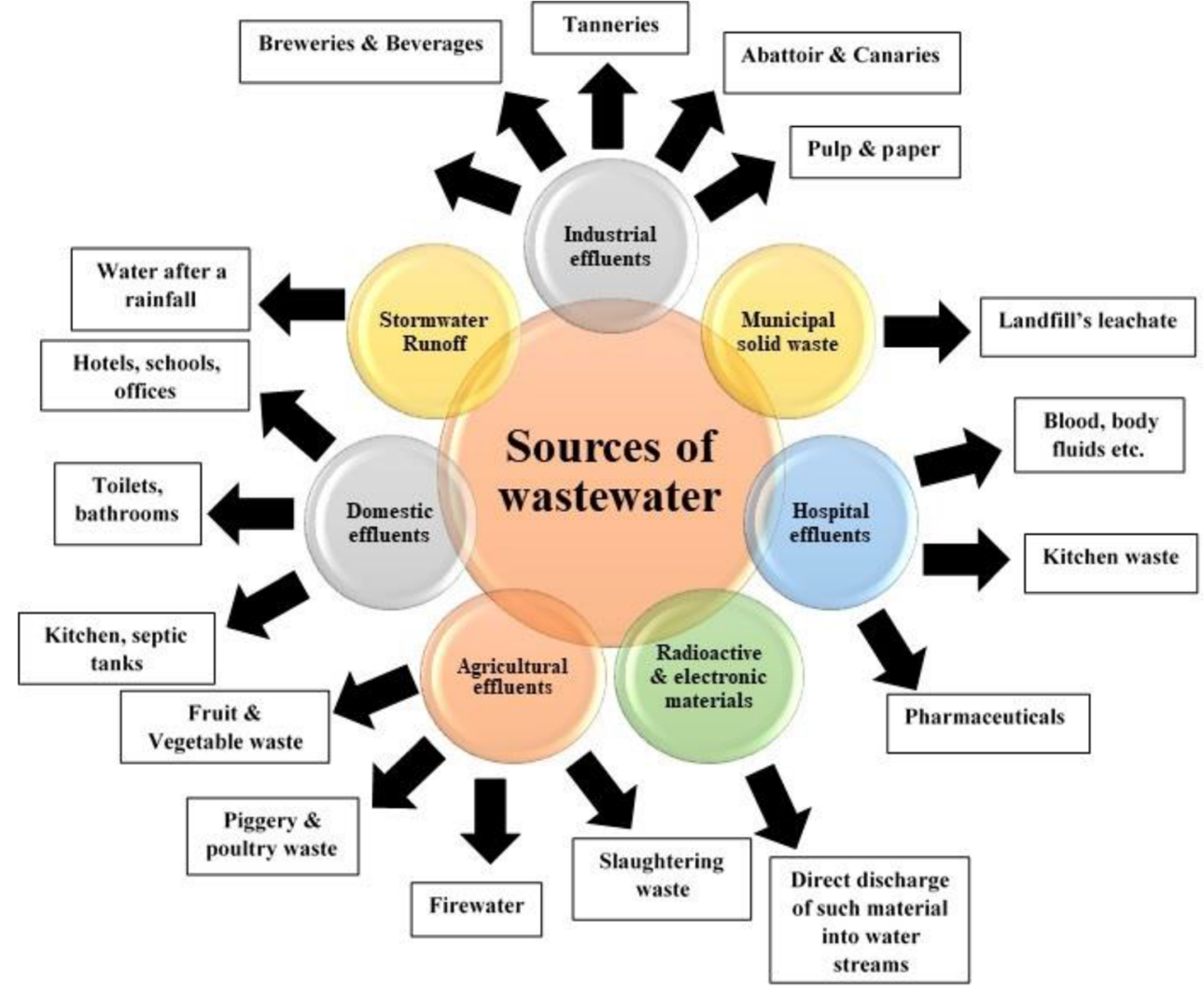

Today, release of raw or carelessly treated wastewater is considered as one of the major reasons behind surface water contamination (Edokpayi et al. 2020). It has been stated that in developing countries, nearly $90 \%$ of untreated sewage is released directly into water streams. Furthermore, on an annual basis, this direct discharge of industrial effluents and raw sewage is around 730 million tonnes, worldwide (Connor et al. 2017). According to recent statistics of the Central Pollution Control Board of India, about 72368 MLD of sewage is generated in India, annually (National inventory of sewage treatment plants CPCB 2021). Besides this, the water report of the United Nations edition in 2018, concluded that by the year 2050 around 6 billion people will suffer from the problem of water scarcity (Boretti and Rosa 2019). However, such inadequate treatment of wastewater can be hazardous for the environment as well as for human health (Edokpayi et al. 2021).

Rapid industrialization and uncontrolled discharge of wastewater are causing contaminants to persist and bioaccumulate in various ecosystems (Nanda and Kumar 2021). Moreover, due to the persistence of current COVID19 pandemic, wastewater analysis becomes a crucial step in order to detect coronavirus transmission in communities, thus providing caution about the possible outbursts of such a contagious disease (Ali et al. 2021). Recently, various studies have revealed the detection of SARS-CoV-2 in hospital sewage and community wastewater (Lodder and de Roda Husman
2020). The genomic sequence of SARS-CoV-2 is around 96.2\% alike to that of "BatCoV RaTG13" bat coronavirus but its transmission rate in humans is much higher as compared to that of MERS and SARs (Yan et al. 2020). As per the evidences, around 2-35\% of COVID-19 patients suffers from gastrointestinal illness like vomiting, diarrhoea, and abdominal pain; however, it is less recurring as compared to respiratory illness (Wang et al. 2020a; Yeo et al. 2020) but this has led to detection of viral RNA in sewage and faecal matter. Coronavirus may find its way into hospital and domestic wastewater through various sources like vomit, handwashing, sputum etc. (Amoah et al. 2020).

Furthermore, it has been stated that around $67 \%$ faecal matter of infected persons tested positive for presence of coronavirus (Chen et al. 2020). Several studies have also revealed the shedding of SARS-CoV-2 from urine of infected individuals (Nomoto et al. 2020). However, viral transmission through wastewater can be a major matter of concern especially in areas where there is lack of proper sanitation and water treatment facilities. In underdeveloped countries, domestic wastewater is discharged directly into the environment which ultimately leaches into groundwater and people residing in peri-urban or rural areas depend on groundwater sources to satisfy their water requirements. Thus, there can be the possibility of coronavirus transmission through untreated wastewater (Thakur et al. 2021). 
Having regard to the concerns referred to above, implementing suitable wastewater treatment technology is therefore a priority in order to protect our environment and human health, which can be effectively solved with the nonthermal Cold Plasma Technology.

\section{Prologue to plasma technology}

The phrase "plasma" was introduced by Irving Langmuir in 1928 to highlight a portion, comprising balanced charges of species like electrons and ions ( $\mathrm{Li}$ et al. 2020). Next to solids, liquids and gases, plasma is considered as the fourth state of matter (Thirumdas et al. 2015) occurring either in ground state or in its excited state possessing a net neutral charge (Mir et al. 2020). To put it another way, it is a fully or partially ionized gas containing neutrals, ions, free radicals and electrons which can be produced by a variety of electrical discharges (Mishra et al. 2016). Nowadays, plasma technology is very well known for its functionalization and decontamination purposes in both abiotic and biotic matrices (Ojha et al. 2020). Usually, it can be classified on the basis of several parameters out of which temperature is the major one, giving it quantitative description. On the basis of temperature, it can be categorized as Hot plasma also known as "Thermal plasma" while Cold plasma also known as "Non-thermal plasma" (Reynamartínez et al. 2018; Li et al. 2020).

Thermal or hot plasma is a type of plasma in which the temperature of heavier species like radicals, ions, molecules and atoms is similar to that of electrons, demonstrating that nearly all of its particles are in thermal equilibrium (Whitehead 2016). It mainly includes radio frequency, torches and arc discharges. This plasma is widely used for processing and treating solid waste including the most recalcitrant waste through plasma gasification or thermal incineration process because in this plasma a high heat flux can be generated by initiating a high amount of power up to $50 \mathrm{MW}$ and extreme pressure levels ( $\geq 105 \mathrm{~Pa}$ ) for its propagation (Ekezie et al. 2017)

On the other hand, non-thermal or cold plasma is another type in which the electrons have much higher temperature, compared to that of heavier species because of difference in their mass thus also referred to as non-equilibrium plasma. Furthermore, on the passage of energy, the gas dissociates into various reactive species followed by ionization, de-excitation or excitation reactions (Ekezie et al. 2017). Earlier, discharges of cold plasma were produced by alternating (AC) or pulsed and stationary (DC) electrical fields and for producing such discharges different types of electrical power supplies like capacitive coupled plasma (CCP), inductively coupled plasma (ICP) or pulsed (DC) plasma were employed (Zainal et al. 2015). But nowadays, atmospheric pressure plasma jets discharge, corona discharge, radio frequency, microwaveinduced plasma, gliding arc discharge, dielectric barrier discharge etc. are widely implemented for producing cold plasma discharges (Guo et al. 2015). These discharges possess numerous advantages making their application commercial. Some of those advantages are listed below in Fig. 2. This non-thermal cold plasma is energy efficient and provides high selectivity in resulting chemical reactions because it does not reveal a localized thermodynamic equilibrium. Therefore, considering all these reasons, application of cold plasma technology is increasing at a very rapid rate and attracting the interest of technologists for wastewater treatment purposes (Jiang et al. 2014).

\section{Different methods of cold plasma discharges used in wastewater treatment}

Dielectric barrier discharge (DBD) is regarded as the "workhorse" of plasma technology (Ojha et al. 2020) as shown in Fig. 3(a). It consists of two flat metal electrodes enclosed tightly in a target chamber out of which, one is usually covered with a dielectric material like mica, glass, ceramics, alumina, quartz etc. generating several micro-discharges due to which there are less chances of electrode etching and spark formation (Ozen and Singh 2020). Between both the electrodes there is movement of any neutral gas or its mixture which undergoes ionization for producing plasma products (Shimizu et al. 2018). But for wastewater treatment purposes, ozone gas along-with air feed or oxygen is used widely (Tichonovas et al. 2013). Furthermore, it is also suitable for decontamination purposes as it offers stability and uniformity in process and avoids the chances of any arc movement from the processing environment (Yong et al. 2015). Additionally, atmospheric pressure plasma jets depicted in Fig. 3(b) is another type of cold plasma discharge consisting of two concentric electrodes in which the outer one is grounded and inner one is coupled with an external power supply like radiofrequency creating radio-frequency energy. On passage of an electric current, it interacts with the gas like oxygen, helium or a mixture of gas causing its ionization (Zhang 2015). Such gases are also helpful in pushing the stream containing active species out of the electrodes through blowing the active portion of the jet (Scholtz et al. 2015). Furthermore, atmospheric pressure plasma jets are simple in construction, commercially available and easy to operate (Ozen and Singh 2020). In this, discharge takes place in a dielectric tube and the electrical energy generally ranges from few $\mathrm{kHz}$ to $27 \mathrm{MHz}$ and power ranges from a few $\mathrm{W}$ up to $\mathrm{kW}$ (Ehlbeck et al. 2010). Figure 3(c) shows the gliding arc discharge of non-thermal plasma which is widely used for wastewater remediation purposes. As compared to other types of discharges, it offers high operating pressure, power and plasma density (Krishna et al. 2016). Moreover, GAD possesses the characteristics of both thermal and non-thermal plasma. It consists of impedance, nozzle, "knife-edge" diverging electrodes between which high 


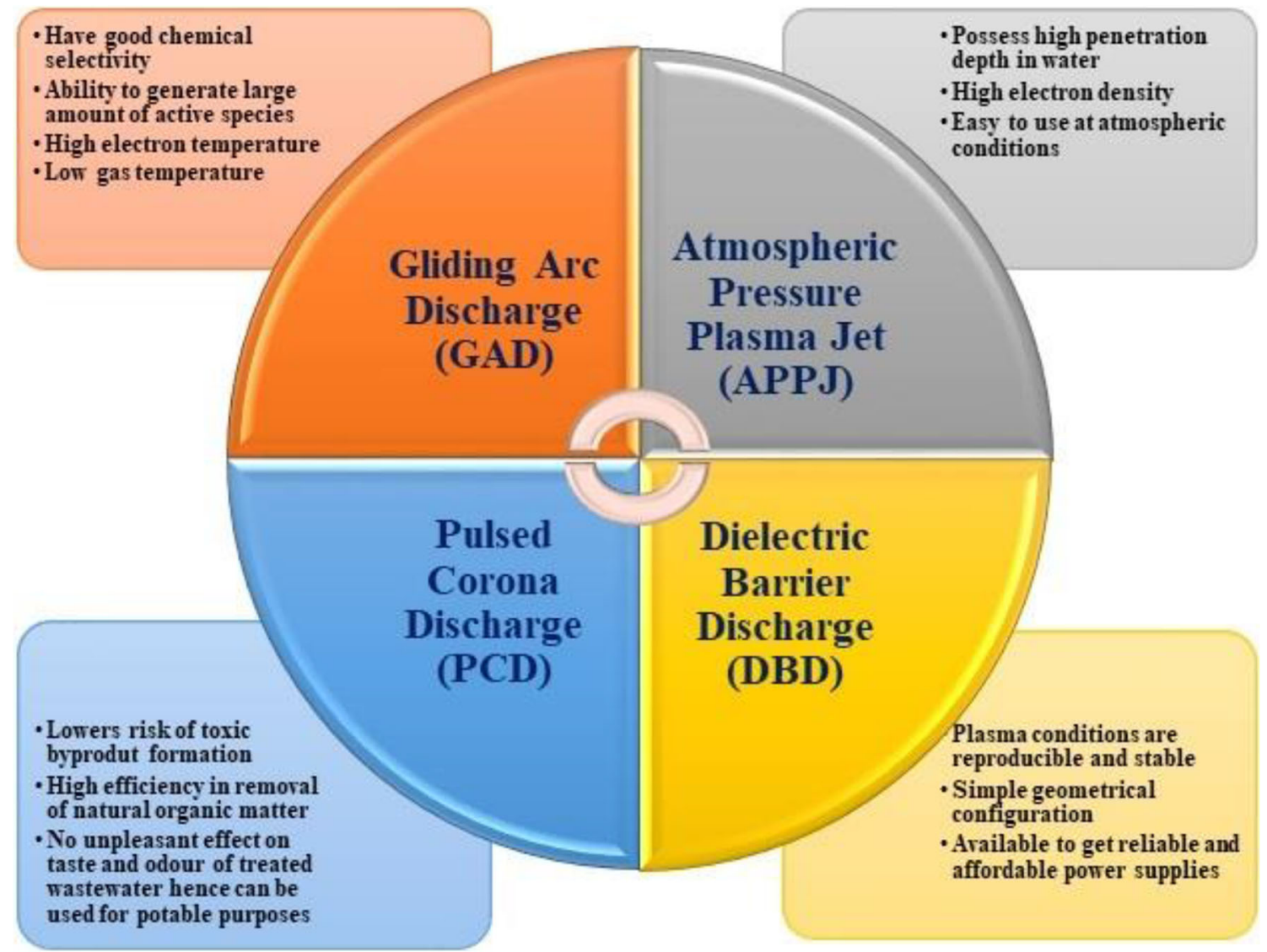

Fig. 2 Advantages of cold plasma discharge types used in wastewater treatment

voltage is introduced, insulating cover and high-power supply and when electric field is approximately $3 \mathrm{kV} \mathrm{mm}^{-1}$, the arc discharge generates. Hence, due to high velocity, the arc length increases (thermal plasma) and temperature of ionized gas decreases, becoming non-thermal plasma (Kim et al. 2014). At atmospheric pressure, this technology is very well known for degradation of various organic components present in water (Tiya-Djowe et al. 2015; Slamani et al. 2018). Pulsed corona discharge is a fourth type non-thermal plasma discharge that is regarded as best for wastewater treatment as shown in Fig. 3(d). Usually, these reactors are in stainless steel and are constructed as a needle, a multiple needle plate and wire. Generally, a high voltage is connected to the pin electrode and the plate electrode is connected to the ground. In the case of multi-pin electrodes, pins were distributed uniformly with a circular shape (Taghvaei and Rahimpour 2016). The reactor is energized by high voltage pulses with short rise time and durations and there is an initiation and propagation of discharge towards grounded plates due to its high curvature characteristic (Ajo et al. 2018). A water solution in plasma in the gas phase would obtain the maximum level of decontamination efficiency.

Many studies on direct current glow plasma discharge in and in contact with liquids published within the last couple of years due to the rising interest in waste water treatment applications. It is also termed as electrode effect in some references depending on which electrode glow discharge takes place. According to the positions of both electrodes, it is classified into two types, i.e. submerged glow discharge electrolysis (SGDE) and contact glow discharge reactor (CGDE). Among these, contact glow discharge reactor has been regarded as an efficient reactor for water purification purposes.

In advanced oxidation process, it is an unconventional method in which electrochemical reactions occurs in the course of an electronic conductor, i.e. electrode and neighboring ionic conductor surface, i.e. electrolyte. In this type of discharge, cathode is immersed in water and isolated from anode through a porous glass. A constant direct current voltage is applied to thin wire anode communicating with surface of electrolyte. Direct current glow discharge is initiated in a thin sheath film of vapor covering the electrode surface, where vapor phase water molecules are electrolytically dissociated at a high temperature into hydroxyl radical and hydrogen radical (Jiang et al. 2014). These radicals can diffuse in the surrounding liquid and be used for the removal of dissolved compounds. Especially, $\mathrm{OH}$ are able to oxidize any organic molecule into "harmless" carbon dioxide in a non-selective way. This makes CGDE as a commercially viable tool particularly for decontamination and sterilization of wastewater treatment. 


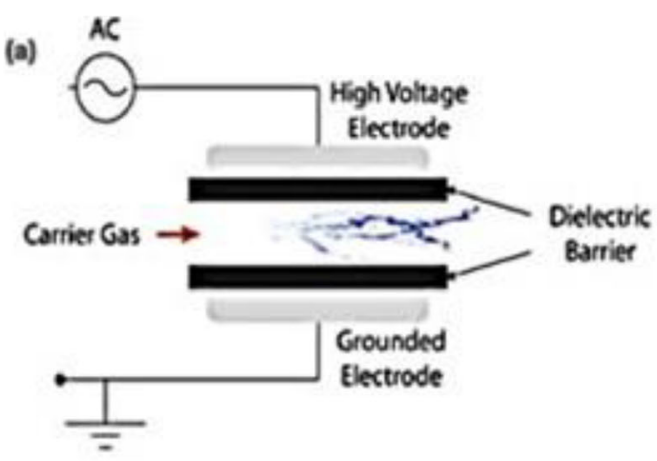

(b)
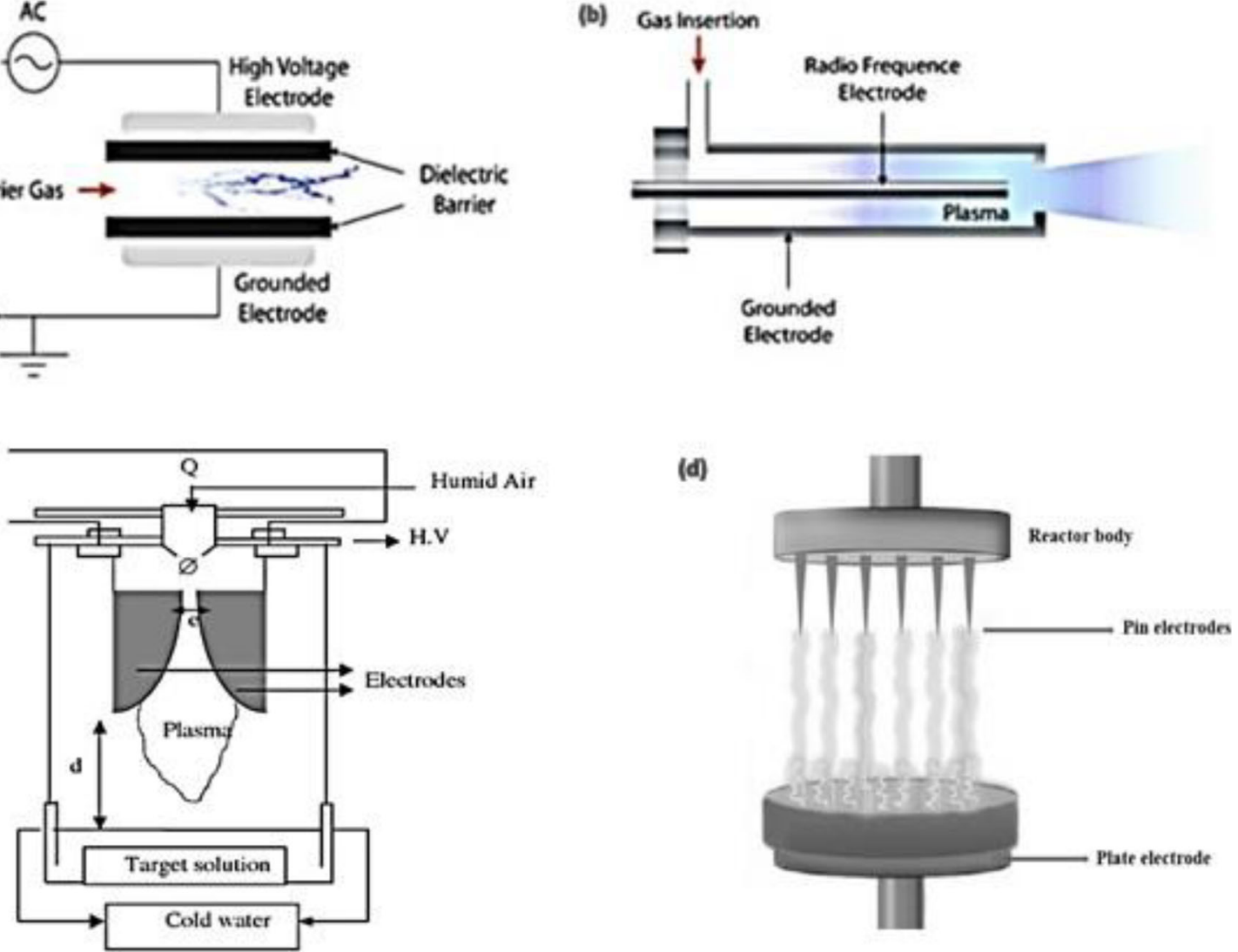

Fig. 3 Different methods of cold plasma discharges used in wastewater treatment a) dielectric barrier discharge; b) plasma jet; c) gliding arc discharge; d) pulsed corona discharge. (Adopted from Ghezzar et al. 2009; Hoffmann et al. 2013; Taghvaei and Rahimpour 2016)

Hence, such type of electrical plasma discharges been studied extensively as effective method for the removal of hazardous chemicals in aqueous solution.

\section{Cold plasma technology working mechanism}

The evolution of an advanced oxidation process for wastewater treatment is a major challenge because for the decontamination of wastewater complete oxidation is needed which cannot be fulfilled by methods like ultrasonication, UV/ozone, photocatalysis etc. (Reddy and Subrahmanyam 2012). Therefore, from the last few years, implementation of nonthermal plasma for wastewater and environmental remediation purposes has gained considerable relevance because of its potential for destroying hazardous organic components in both wastewater and in raw water. The efficiency of this method has been examined for a range of reasons such as decontamination of numerous harmful elements contained in water such as medicinal products, organic dyes, pesticides, herbicides, biomolecules, phenolic compounds, and antibiotic substances. It also works to decrease TOC and COD in treated wastewater by enhancing the biodegradability and eradication of different pathogens including bacteria, fungi, and viruses (Zeghioud et al. 2020). Various studies have revealed the antimicrobial efficacy of cold plasma technology (Lunov et al. 2016; Lu et al. 2014; Kim et al. 2014). Furthermore, it is also an emerging technique in the biomedical sector for treating wastewater and inactivating microbes (Patange et al. 2018). Hence, a detailed general mechanism of this novel technology for treating wastewater and inactivating pathogenic micro-organism is discussed below.

\section{a. General mechanism for treating wastewater}

Discharge plasma is a very well-known process for total mineralization and elimination of occurring pathogens in wastewater (Abdul-Majeed et al. 2015). The main reason behind the fact is that due to physico-chemical impact of plasma there is generation of oxidizing species: radicals $\left(\mathrm{O}^{-}, \mathrm{OH}^{-}, \mathrm{H}^{-}\right)$ that might diffuse into shockwave, UV light, liquids, and molecules $\left(\mathrm{O}_{3}, \mathrm{H}_{2} \mathrm{O}_{2}\right)$ and electrohydraulic cavitation may degrade the pollutants present in wastewater or decomposes the pollutants into another compound. In case of a liquid and gas, plasma can be generated either in gas above the liquid or in liquid directly and if there are hybrid reactors, it can be generated in both gas and liquid. But the most effective method that requires less power consumption for treatment is the diffusion of gas phase into liquid phase (Thirumdas et al. 
2015). Figure 4 depicts the working mechanism of plasma discharge for treating wastewater.

b. General mechanism for inactivation of bacteria and fungi

The antimicrobial efficiency of discharge plasma is also due to similar reasons as discussed above, i.e. generation of reactive oxygen species and is considered as the primary mechanism evolved in its inactivation. Studies have revealed that genetic material, proteins and cell envelopes of pathogenic microorganisms are target points for plasma resulting in their inactivation (Sharma et al. 2018). When the microbial cells are treated with plasma, there is formation of malondialdehyde which disrupts their genetic material leading to cell death. Particularly, when produced species interrelate with water, there is generation of hydroxyl ions which are most deleterious and reactive to pathogenic cells. Furthermore, it has been stated that hydroxyl radical is the main reason behind $90 \%$ of DNA destruction along with damaging cell components and cell membrane (Thirumdas et al. 2015). Figure 5 depicts the working mechanism of plasma discharge for inactivating pathogenic microorganisms (bacteria and fungi). As soon as the electrical discharge reaches liquid, they generate several physical and chemical effects which are responsible for detrimental inactivation of pathogenic microorganisms.

- Initiation of pores in cell membranes as generated reactive species interact with microbial cell membranes.
- Disruption of cell structure due to shockwaves ranging between 5 and $20 \mathrm{kBar}$.

- Destruction of DNA strands when exposed to UVradiation ranging between 200 and $400 \mathrm{~nm}$ due to mutation (Abdul-Majeed et al. 2015; Bhatnagar 2019).

iii. General mechanism for viral inactivation

Virus is the most abundantly found microorganism which has a potency to harm all living organisms from humans to plants, animals and bacteria (Nasir and Caetano-Anollés 2015). They are seen as one of the main sources of various illness outbreaks, some of which are life-threatening (Filipić et al. 2020). It can either be transmitted directly from one infected person to another or indirectly such as surfaces, water, air, food, or objects. Amongst all, water is turning as one of the main routes for transmission of pathogenic viruses (Van Doremalen et al. 2020; Shrestha et al. 2018). Today, the foremost reason behind insufficiency of potable water is the conveyance of various waterborne pathogenic viruses.

In addition, the demand for inactivation of the virus was quite rapid compared to previous ones because of the ongoing highly contagious COVID-19 pandemic produced by SARS$\mathrm{CoV}-2$ or coronavirus as the respiratory virus. Therefore, all these elements can provide an effective, new and promising option for inactivating viruses with the purpose of using cold plasma technology to achieve a better life and stop coronavirus spread. Various studies have also shown how antivirals in different viruses such as respiratory virus A and B, respiratory

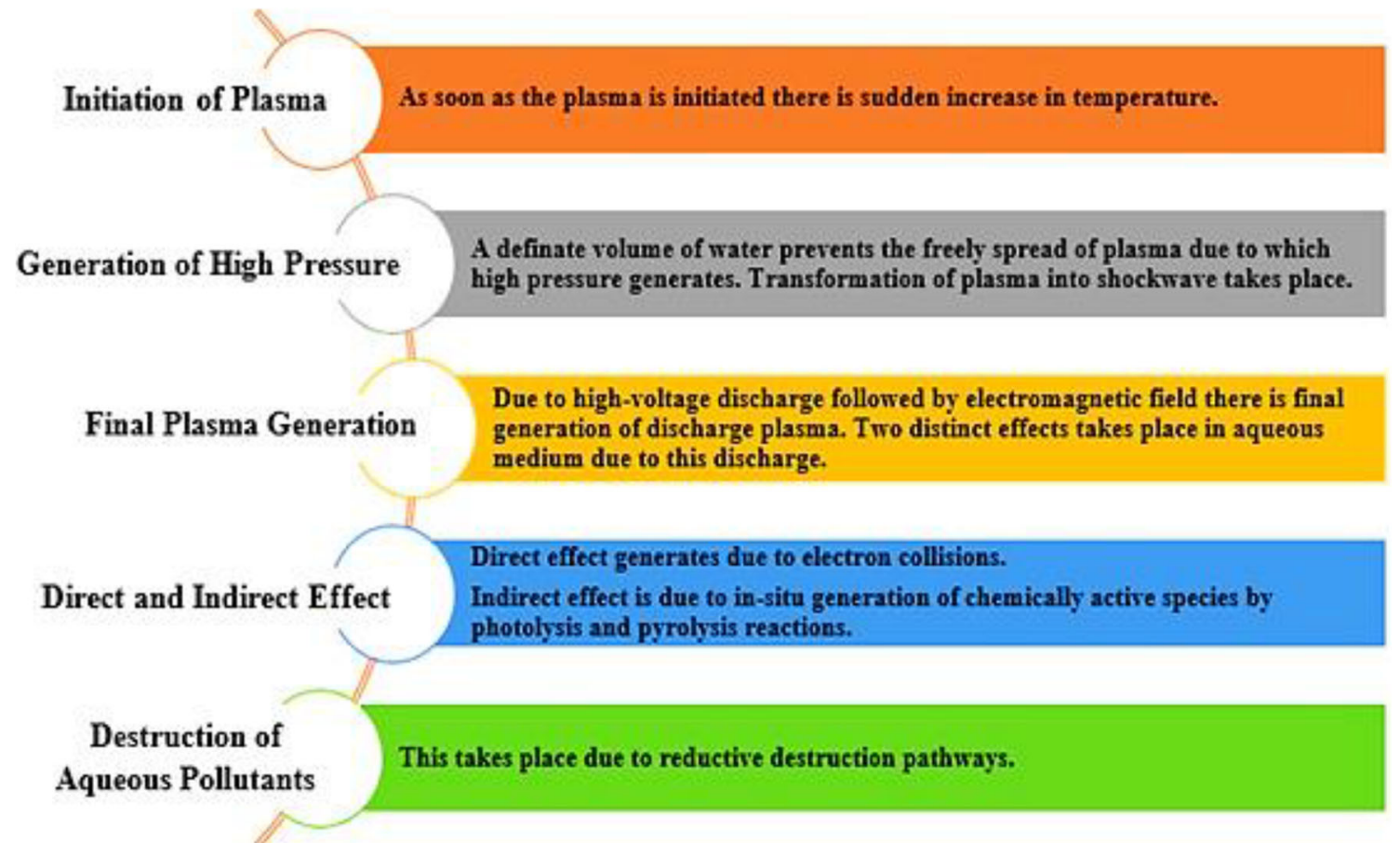

Fig. 4 Working mechanism of cold plasma for treating wastewater 


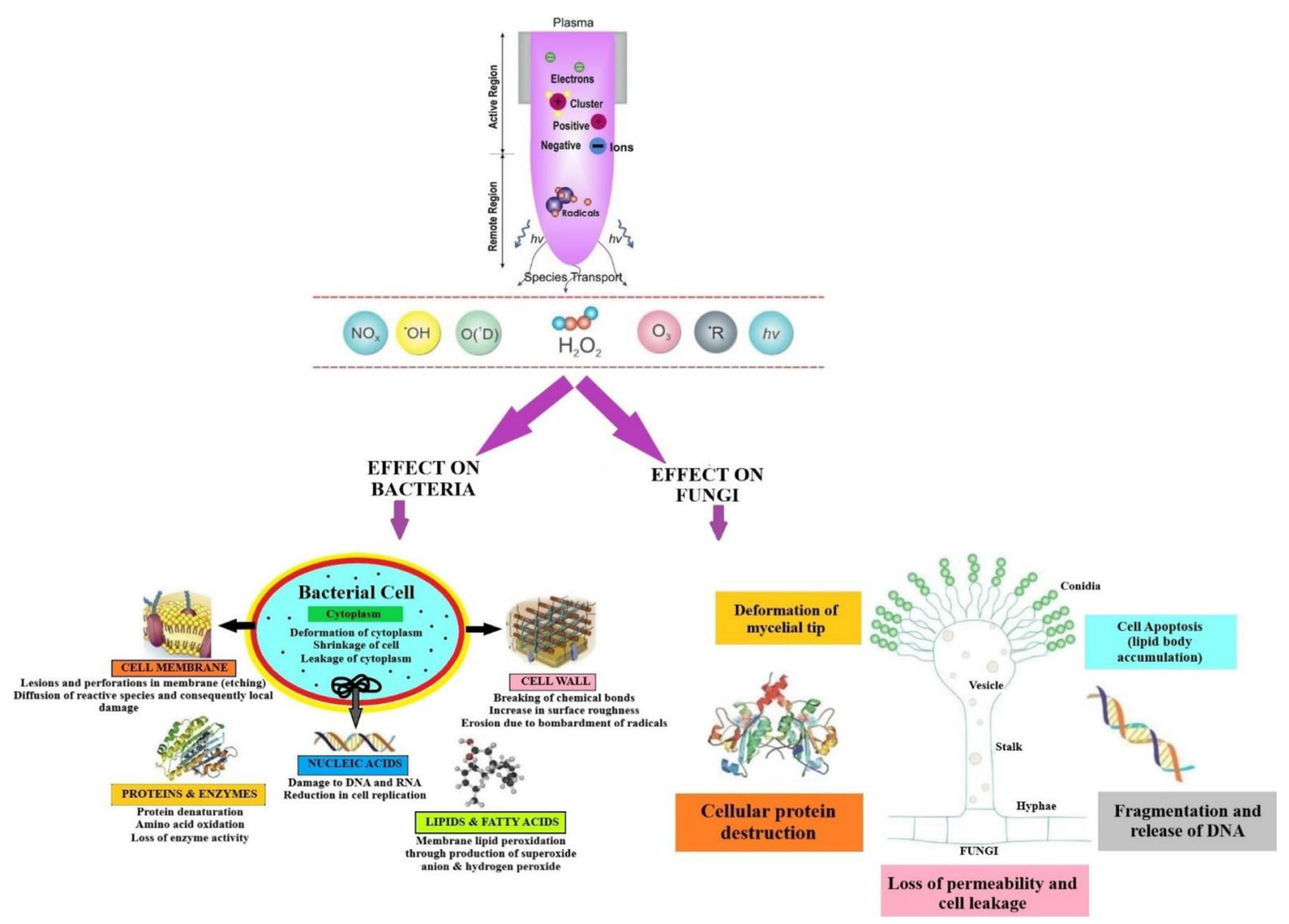

Fig. 5 Working mechanism of cold plasma for inactivating pathogenic microorganisms (Adopted from Misra and Jo 2017; Misra et al. 2019)

syncytial virus, etc. are effective for deactivation of several viruses (Filipić et al. 2020).

Generation of reactive nitrogen species or reactive oxygen species is considered as the primary mechanism of cold plasma for inactivating viruses. The plasma is aimed at viral capsid, protein and nucleic acid, therefore compromising their genomic and structural integrity. Due to the effects of reactive species, there is loss of virus infectivity damaging the binding of virus with the host cell receptors. In addition, the infectious property of the virus will be lost in the event of a genetic material disruption because the replication and translation of a genome is very crucial. It has been stated that generated reactive species can damage the outer protein layer also by penetrating RONS to the genetic material of virus (Filipić et al. 2020). Figure 6 depicts the working mechanism of plasma discharge for inactivating viruses.

\section{Parameters affecting the efficiency of cold plasma technology in wastewater treatment}

Various studies have reported several factors significantly affect the process efficacy of cold plasma discharge in treatment of wastewater. These factors include input power, designing of electrode and reactor systems, pollutant concentration, $\mathrm{pH}$ and temperature of solution, conductivity of water, type and composition of feed gas used etc. (Zighoud et al. 2020). For instance, input energy or power plays a very vital role in effective mineralization and degradation of pollutants as with an increase in input power, the rate of removal also increases (Wang et al. 2016). Moreover, the designing of plasma reactor systems should be such that there can be maximum energy utilization at a given power input. Generally, the plasma reactors are made up of Perspex or glass like rectangular parallelepiped vessels or in the form of reaction column type reactors that can be employed for batch, continuous or circulating-flow mode. Similarly, in the case of electrode designing, the main point to be taken into consideration is high compatibility of electrode with reactor and wide zone for electrical discharge. Usually, for plasma generation two asymmetric conductive mediums possessing high curvature are used as electrodes (Jiang et al. 2014).

Furthermore, studies have also observed the effect of initial pollutant concentration on removal efficiency. With an increase in initial concentration of pollutants the reaction rate also increases till the formation of reactive species sets off as a restraining step in treatment (Wang et al. 2016). The $\mathrm{pH}$ of the reaction medium also plays a very important role in assessment of plasma discharge potential. A proportional relationship has been revealed between $\mathrm{pH}$ and decontamination efficacy of certain aqueous pollutants (Yan et al. 2013; Kim et al. 2013). Similarly, temperature also has a significant effect on degradation potential of several pollutants present in 
Fig. 6 Working mechanism of cold plasma for inactivating viruses. (A) Morphologically different viruses treated with $\mathrm{CP}$. (B)Close-up of CP properties responsible for virus inactivation. The most essential moieties in virus inactivation are reactive oxygen and/or nitrogen species (RONS), although UV radiation and charged particles (e.g. ions, electrons) can also play a role. Molecules in the ground state are neutral and do not have any effects on virus inactivation. $\mathrm{CP}$ can target both viral proteins and nucleic acids (or even the virus envelope, when present). (C) After $\mathrm{CP}$ treatment, the virus particles and nucleic acids are partly or completely degraded to noninfective particles that cannot cause harm to their hosts (Adopted from Filipić et al. 2020)

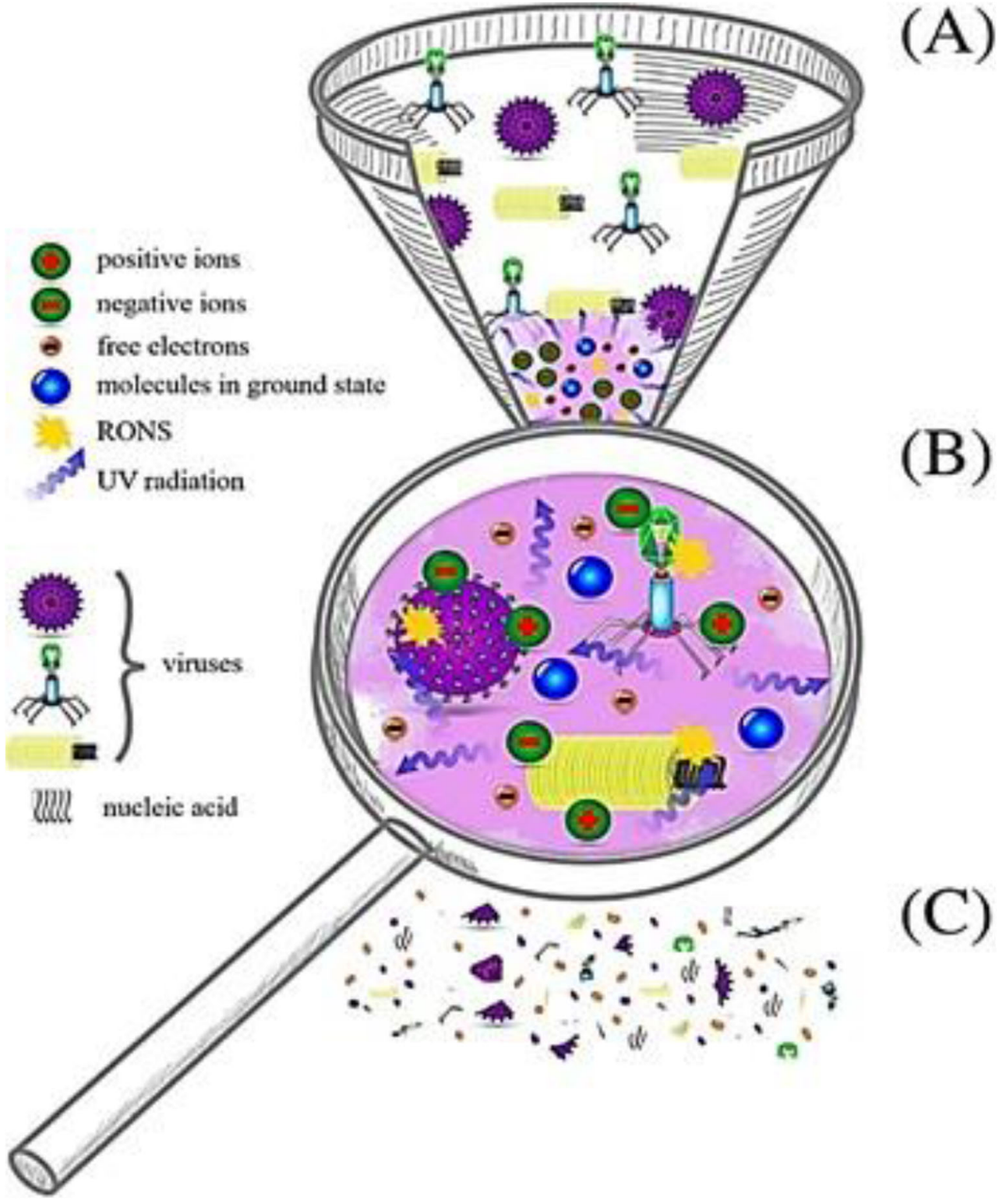

wastewater (Jiang et al. 2012). The composition and type of feed gas used in cold plasma discharge possess a significant effect on treatment efficiency. Moreover, the electrical conductivity of liquid medium also greatly influences properties of discharge and ultimately formation of reactive species in discharge plasma (Zeghioud et al. 2020). A list of factors affecting process efficiency of cold plasma are mentioned below in Fig. 7.

\section{Implementation of cold plasma technology for treating wastewater and inactivating pathogenic microbes.}

As compared to other advanced oxidation methods like electrochemical oxidation (Bakheet et al. 2018), photocatalysis (Zhang et al. 2015), Fenton process (Liu et al. 2018a) etc. non-thermal plasma technology currently has received great attention in the field of wastewater treatment along with inactivating harmful pathogenic microorganisms present in water (Magureanu et al. 2018; Guo et al. 2018; Patange et al. 2018) thus making water suitable for potable purposes. Furthermore, this technology does not demand any precursor or catalyst like hydrogen peroxide or $\mathrm{TiO}_{2}$ coupling with UV light for generation of hydroxyl radicals. Hence, considered as an eco-friendly technique. Moreover, it also remains unaffected by penetration depth of ultraviolet radiation and turbidity of wastewater (Schneider et al. 2020).

Nonetheless, several studies have revealed the high efficiency of cold plasma technology in removing harmful toxic components from wastewater and inactivating pathogenic microbes. Like, Iervolino et al. (2019) examined the efficiency of dielectric barrier discharge NTP reactor in removing 


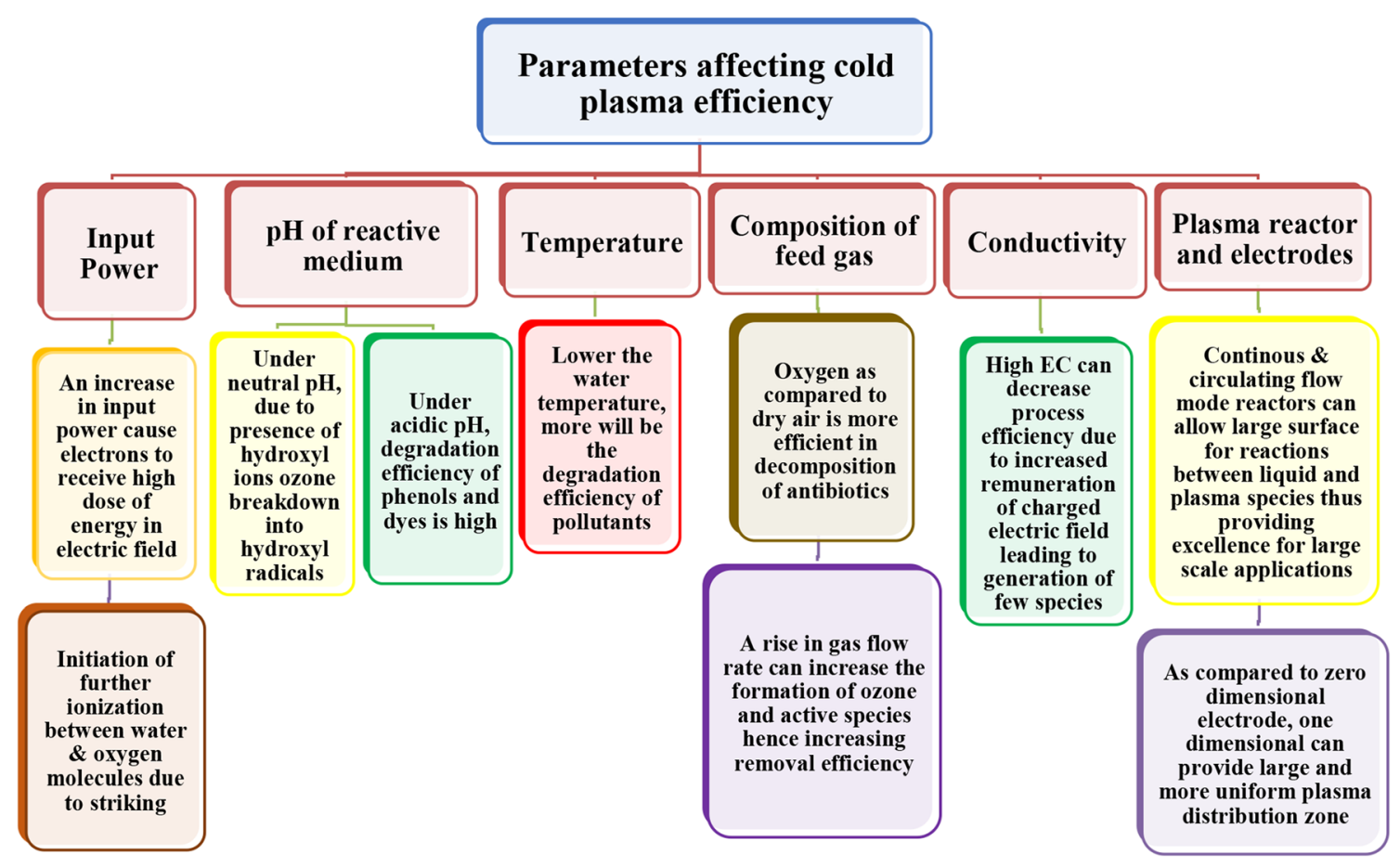

Fig. 7 Process parameters affecting efficiency of cold plasma in wastewater treatment

various water pollutants like phenol, ceftriaxone, caffeine, methylene blue and paracetamol. The study revealed that there was complete mineralization and degradation of ceftriaxone and methylene blue after treating only for $5 \mathrm{~min}$ at $20 \mathrm{kV}$ voltage with application of oxygen as a process gas while the complete mineralization and degradation time for paracetamol and phenol was $15 \mathrm{~min}$ and $25 \mathrm{~min}$ for caffeine, respectively. Furthermore, it was concluded that dielectric barrier discharge NTP reactor has a better efficiency in removing organic water pollutants as compared to other non-thermal technologies.

Similarly, Krishna et al. (2016) studied the efficacy of gliding arc plasma discharge system for degradation of verapamil hydrochloride in water. The results revealed that initially, concentration of verapamil in water was $5 \times 10^{-5} \mathrm{M}$ and $5 \times 10^{-4} \mathrm{M}$. However, after treating for about $80 \mathrm{mins}$ there was a significant reduction in initial concentrations by $97 \%$ and $37 \%$, respectively. Wang et al. (2020b) also studied the efficacy of dielectric barrier discharge plasma in removing tetrabromo bisphenol A (TBBPA) from wastewater and concluded that the performance for removal of TBBPA was very rapid and highly efficient.

Additionally, Slamani et al. (2018) investigated the efficiency of gliding arc plasma discharge in combination with the Fenton process for degrading paracetamol in aqueous solution. The study revealed that paracetamol was completely degraded after combined GAS at $10 \mathrm{kV}$ and Fenton treatment. Furthermore, after a treatment time of $0.5 \mathrm{mins}$, the mineralization content also increased by $58.7 \%$ from $20.1 \%$ and this increment possessed the same tendency at $30 \mathrm{mins}$ and $60 \mathrm{mins}$ treatment time. Similarly, the removal efficacy of total organic carbon also got enhanced and this reduction was 3 to 4 times higher as compared to that in single GAD or Fenton treatment. After 10 days, the highest values of TOC removal were 96.8 $\%, 92.2 \%$ and $95.1 \%$ while it was $49.6 \%$ after 21 days when only GAD treatment was applied.

Similarly, Wang et al. (2020c) designed a micro hollow cathode excited DBD plasma for improving the treatment efficacy of organic wastewater in which the target organic pollutant was P-chlorophenol. It was observed that after treating for $30 \mathrm{~min}$, the highest removal of P-chlorophenol and dichlorination ratio was about $99 \%$. Hence, the study concluded that micro hollow cathode excited DBD plasma possesses the efficiency of treating organic wastewater. Likewise, García et al. (2017) investigated the efficiency of microwave atmospheric pressure plasma jets for MB-laden water in which argon was applied as a feed gas. The study reported that degradation of methylene dye was greater at low concentration of dye. Additionally, this degradation rate got further increased with an increase in the flow rate of argon gas and it was also found that when multiple plasma applicators were applied instead of single the degradation efficiency was better as compared to those in single applicators under the same input power and total flow.

Similarly, Ekanayake et al. (2021) reviewed the potential of non-thermal plasma for water purification and desalination purposes and concluded that this novel technology can be an effective tool in achieving such goals. It possesses the efficacy of improving water purification and desalination purposes making them more effective and energy efficient. In 
addition, it will minimize discharge of harmful contaminants into the environment.

Furthermore, Abia et al. (2015) observed the synergistic effect of gliding arc plasma discharge and biosorption system for removing glycine and nitrophenol from an aqueous solution. The study reported that after treating for 1 hour the total organic carbon concentration was $658 \mathrm{mg} / \mathrm{L}$ from $950 \mathrm{mg} / \mathrm{L}$. Furthermore, on treating for 6 hours this concentration reached up to $460 \mathrm{mg} / \mathrm{L}$. also, when plasma treatment was combined with a bio sorbent (Jatropha shell) the concentration on total organic carbon was significantly reduced to $530 \mathrm{mg} / \mathrm{L}$ and $280 \mathrm{mg} / \mathrm{L}$ after 1 and 6 hours of treatment, respectively. Hence, it was also concluded that the efficiency of plasma treatment can be improved by incorporation of such modified horticultural residues. The effect of different cold plasma discharges on pollutants present in wastewater are mentioned in Table 1.

Moreover, Ott et al. (2021) also demonstrated the potential of high voltage atmospheric cold plasma for inactivating spores of Aspergillus flavus. The applied voltage was 70, 80, and $85 \mathrm{kV}$ for $0,1,2,5$, and $10 \mathrm{~min}$, respectively. The study concluded that after exposure, the fungal spores were significantly reduced by $46.85 \%, 23.86 \%, 13.47 \%$, and $4.54 \%$ with $1,2,5$, and 1 min treatment time. Furthermore, a change in morphology of fungal spores was also observed after treatment as compared to non-treated spores. There was destruction of the outer cell wall and treated spores were shrunken and irregularly shaped and initially, the colour of fungal culture was yellow to green. But after treatment, a change in colour to pale yellow or white was observed which got increased with exposure time. A decrease in density was also observed in treated spores.

Likewise, Van Nguyen et al. (2020) investigated the efficiency of cold plasma technology (corona discharges) using a high voltage source $(18 \mathrm{kV}-29 \mathrm{kHz})$ for treating groundwater to be supplied for domestic purposes. The study revealed that after treatment the E. coli population was less than $3 \mathrm{MPN} /$ $100 \mathrm{ml}$ while its initial concentrations were 7.33 and 722.67 $\mathrm{MPN} / 100 \mathrm{ml}$ at $2 \mathrm{~L} / \mathrm{min}$ flow rate with $30 \mathrm{~min}$ water retention time after treatment. Additionally, the arsenic and iron content were also reduced to great extents. However, the efficacy of cold plasma treatment was not high enough in removing arsenic but it got increased in combination with ferric ions. At last, it was stated that the quality parameters of treated groundwater met all the requirements of WHO guidelines and Vietnamese standards.

Similarly, Chandana et al. (2018) studied the efficacy of non-thermal atmospheric pressure plasma jets for reducing bacterial load in an aqueous solution and concluded that such non-thermal plasma technology can be a substitute for sterilizing thermo-labile and vacuum sensitive living tissues. Likewise, Kim et al. (2014) investigated the efficiency of gliding arc discharge plasma for inactivating $E$. coli in water.
The study concluded that there was significant inactivation (of around $99.9 \%$ with $5 \log$ reduction) in the population of $E$. coli during a storage period of $4 \mathrm{~h}$ after being exposed to plasma treatment. Production of strong anti-microbial properties by GAD was also reported. A decrease in $\mathrm{pH}$ of up to 3.26 was observed in treated water.

Furthermore, Lee et al. (2011) examined the efficiency of streamer corona discharge process for inactivation of MS2 bacteriophage in water. It was observed that after treatment the virus got rapidly inactivated (approximately up to $4 \log$ reduction in $5 \mathrm{mins}$ ). Hence, the study concluded that streamer corona discharge process can significantly inactivate MS2 bacteriophage. However, with an increase in charge storage capacitance and applied voltage the reduction rate of viral pathogens also increased. The effect of different cold plasma discharges on pathogenic micro-organisms including viruses present in wastewater are mentioned in Table 2.

\section{Future challenges and scope of cold plasma technology}

Nonetheless, in recent years, there has been a considerable surge in interest in the use of cold plasma technology for wastewater treatment. Today, the problem of shortage of potable water resources is escalating fast for a variety of reasons, and it has the potential to become a serious concern in the near future if the surplus creation of wastewater is not adequately addressed. Furthermore, SARS-Co-V-2 or coronavirus transmission through wastewater has recently been observed, which is a significant issue that might lead to a faster spread of the COVID-19 outbreak.

Cold plasma technology can be seen as a promising approach for resolving the problems related to wastewater treatment but requires more development and research as there are various challenges that are yet to be confronted. Consequently, there is a necessity to further analyze and discuss the shortcomings of this particular process so that its utilization can be commercialized.

In particular, the efficiency of plasma depends upon a number of factors like which type of gas is used, energy input, properties of liquid, source of excitation etc. For instance, high consumption of gas is considered as a drawback towards large scale application of cold plasma technology. Hence, advancement and production of physical effects including reactive species for decontamination purpose needs to be explored further so that the treatment process can be optimized hypothetically along with comprehensive explanation of its oxidation mechanism (Ognier et al. 2009; Dojcinovic et al. 2011).

Aside from the aforementioned criteria, the deployment of cold plasma treatment on a wide scale will also be determined by capital investment, competent application, liveability, and process running costs (Zeghioud et al. 2020). Thus, there is a 


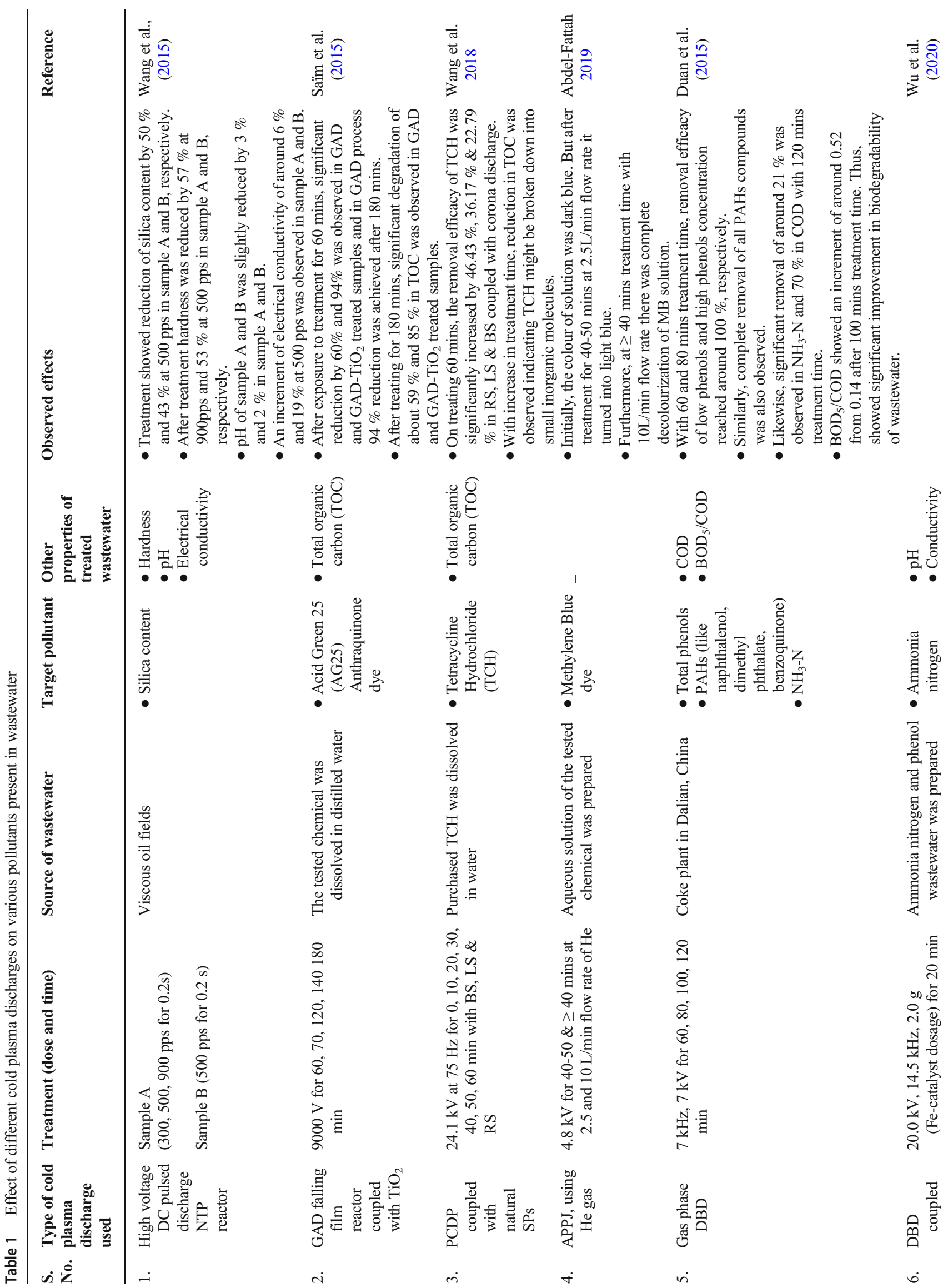




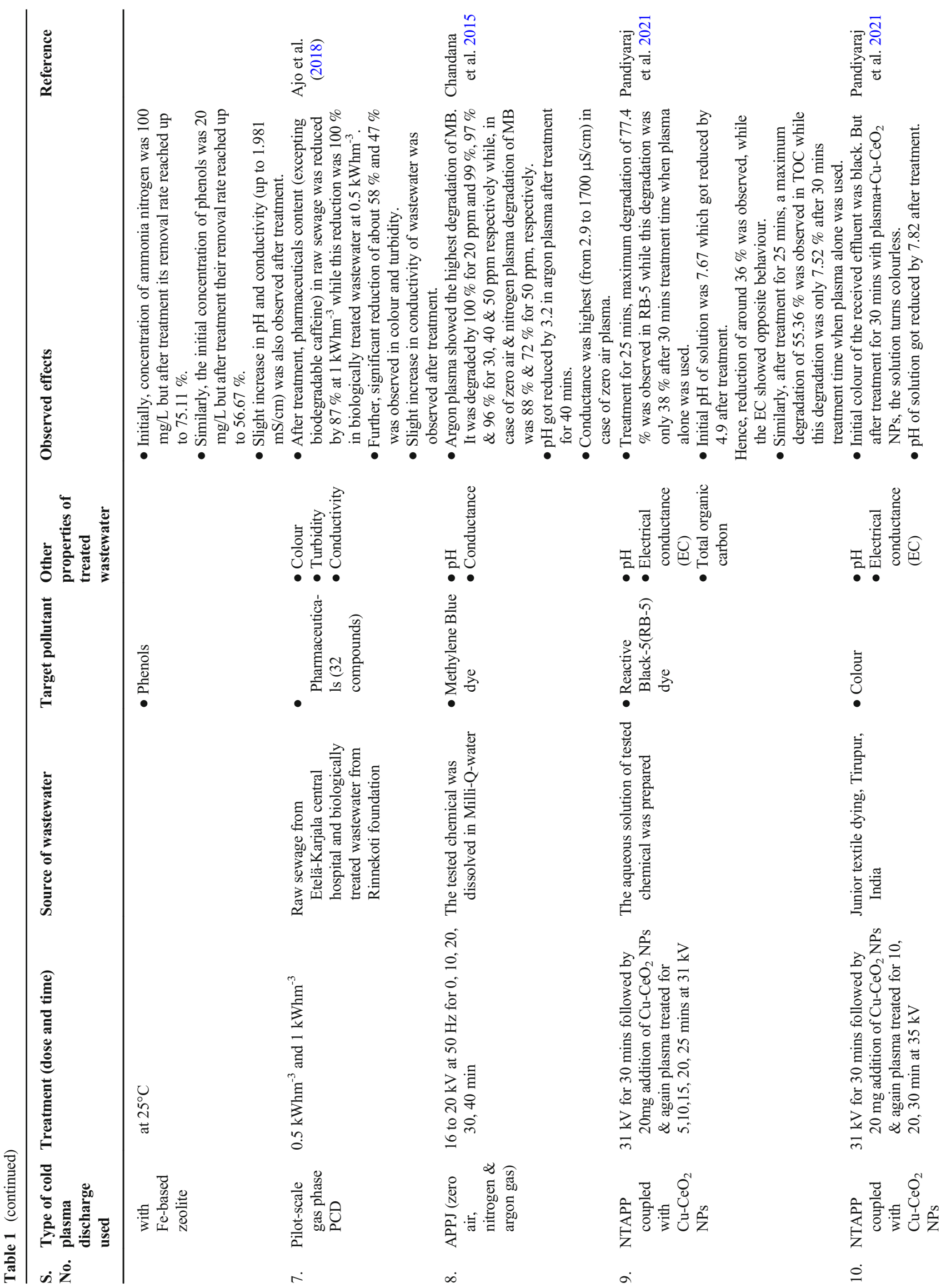




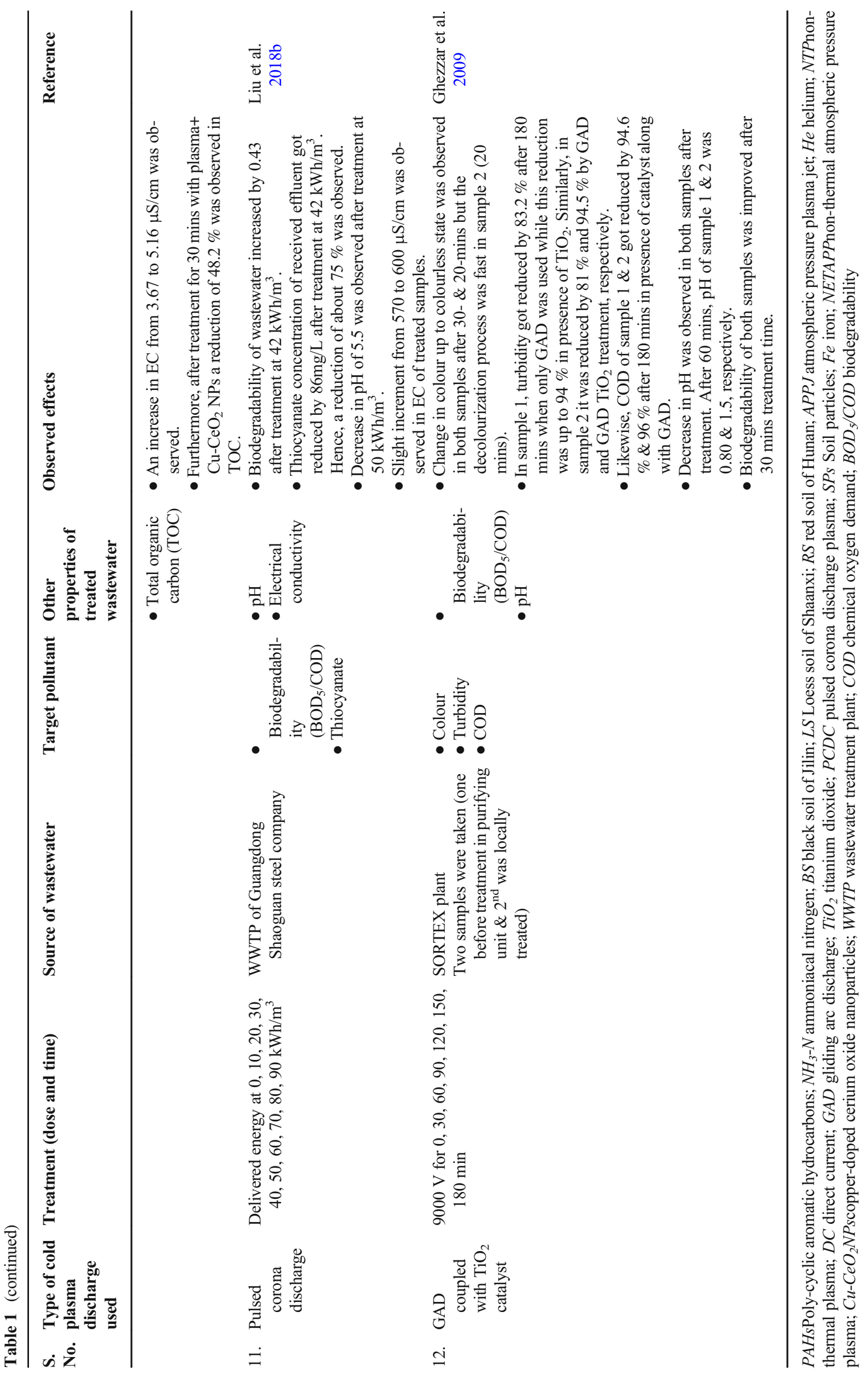




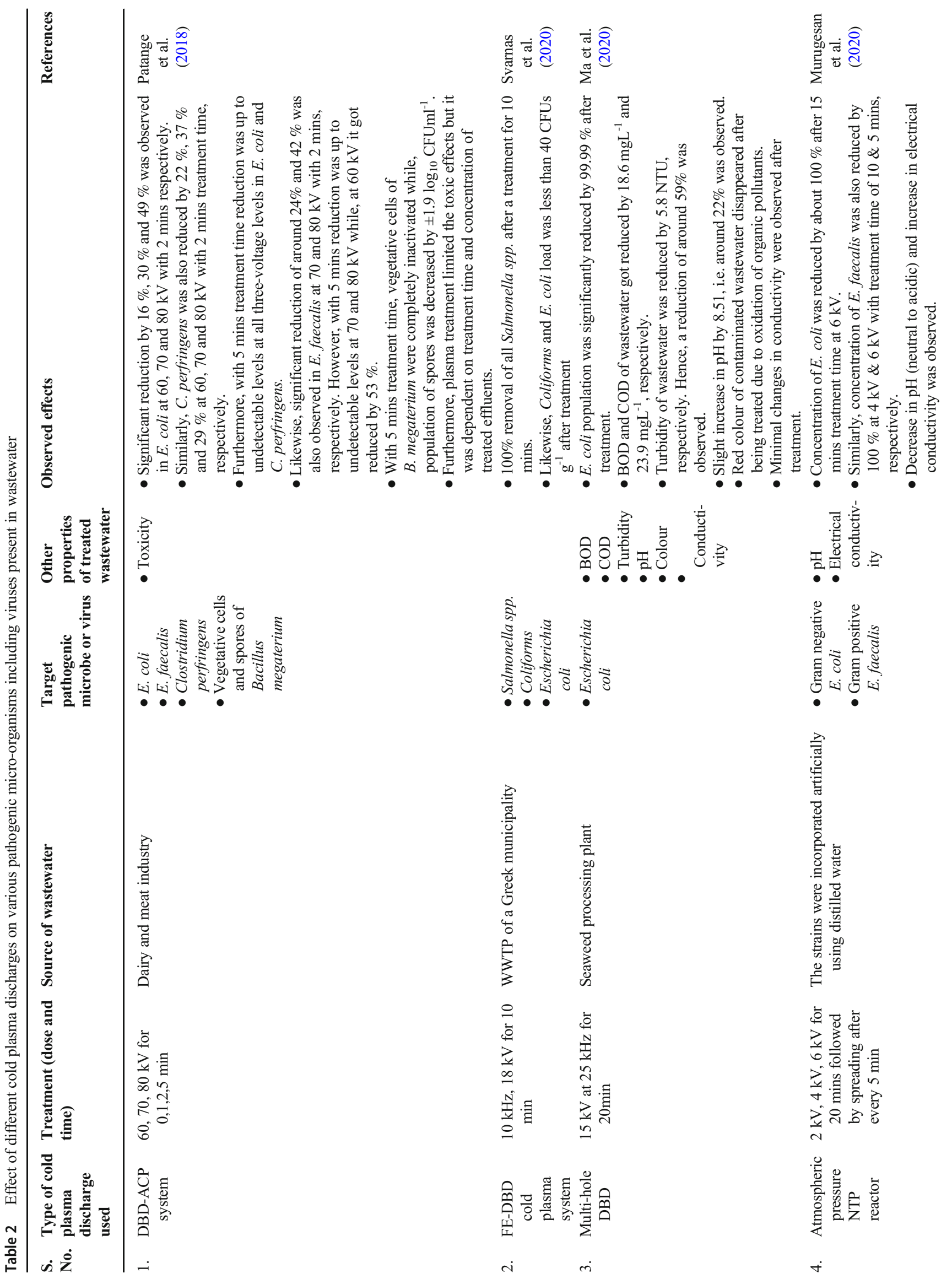




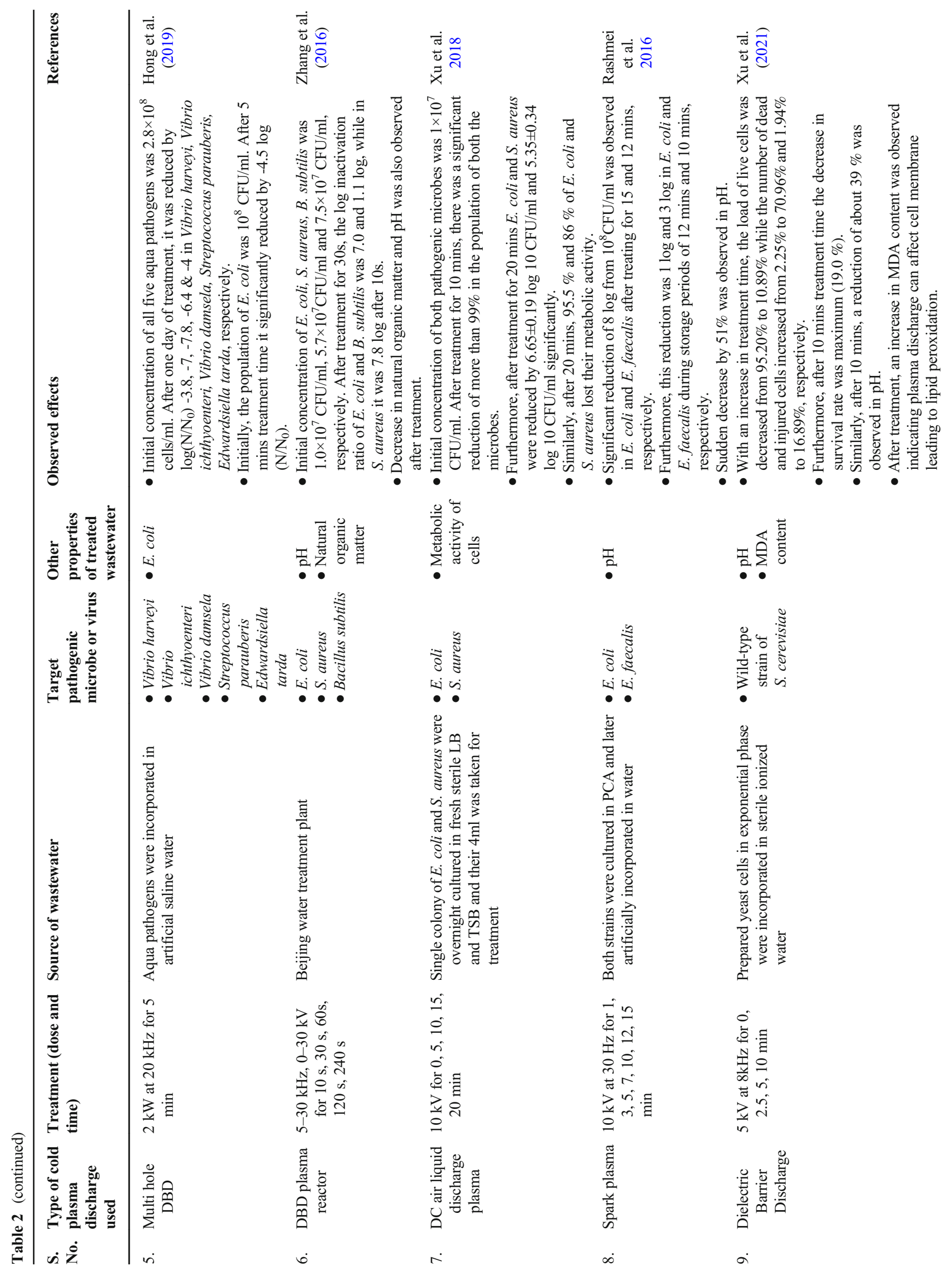




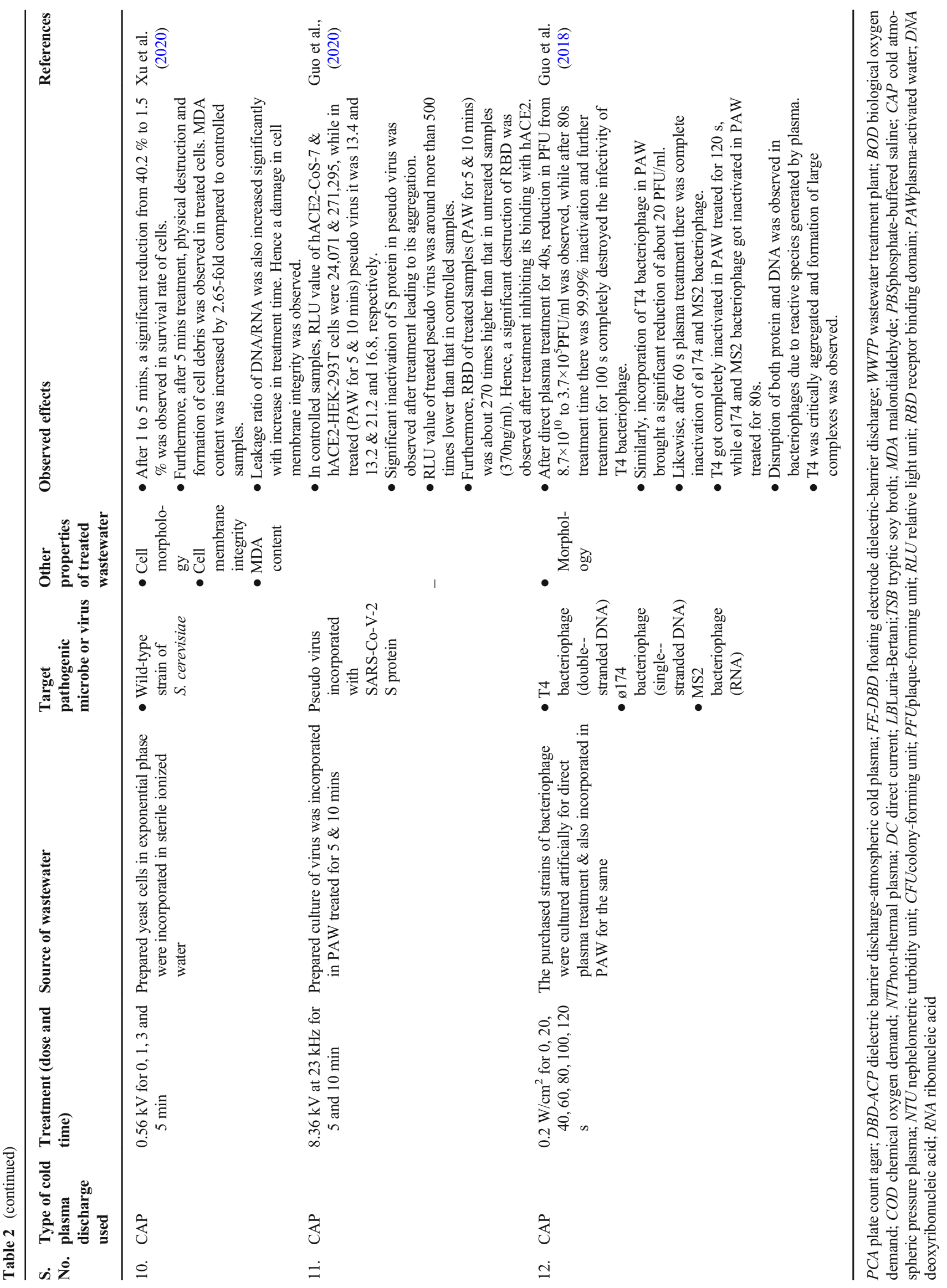


significant need for comprehensive research to identify the capacity of different plasma equipment since the chemistry of plasma is reliant on its source, producing variance in the process. As a result, the industries will specifically recognize an affordable and scalable plasma system (Gavahian et al. 2019).

Furthermore, there is a need for a thorough investigation into the presence of long-lived oxidants in exposed water, as well as the type of by-products generated during the oxidation process, in order to confirm that there will be an adequate and continuous reduction in overall toxicity after treatment, as the production of highly toxic by-products is a possibility (Zeghioud et al. 2020). Additionally, plasma reactors designed to meet the goal of wastewater treatment are extremely challenging and complicated, necessitating the use of theoretical information in order for plasma reactor scale-up to be efficient. Precisely, some notable issues that should be taken under consideration for designing a wastewater treatment system are as follows:

a. Characteristics of wastewater and pollutants to be treated.

b. Suitability of plasma reactor and type of discharge used.

c. Biodegradability and toxicity analysis of intermediates produced by plasma discharge.

d. Cost-effectiveness of the process (Jiang et al. 2014).

As a result, the accuracy of cold plasma technology should be thoroughly examined for its normal working lifetime, preferable efficient sustainability, and operation safety so that the process of wastewater treatment can be successfully proposed, as there are still several obstacles that must be overcome in order to meet the demand of industries.

Several previous researches have demonstrated the potential effectiveness of plasma discharge in decontaminating wastewater by significantly lowering the amount of certain aqueous pollutants up to a remarkable level. Besides this, researchers have noticed a consequential reduction in several water-borne pathogenic microorganisms including viruses (Wang et al. 2015; Patange et al. 2018; Ma et al. 2020; Guo et al. 2018). Similarly, Guo et al. (2020) recently demonstrated substantial inactivation of S protein in plasma activated water to inhibit coronavirus transmission. However, more study on the effect of plasma discharge on SARS-Co-V 2 is required in order to prevent disease transmission.

Looking forward, application of cold plasma in the field of wastewater treatment might be a viable solution to the aforementioned issues. The scope and existence of cold plasma alone or in conjunction with other suitable treatment can be fairly broad for wastewater remediation for future use. However, additional research is needed to have a deeper knowledge of its functioning mechanism and good results. Furthermore, there is a fundamental necessity for resolving the aforementioned problems and overcoming process constraints so that the sustainability of technology may be improved further to be effectively applied on an industrial scale.

\section{Conclusion}

In recent decades, the plasma technology used for raw and industrial wastewater treatment has been a major focus of academics and technologists due to significant increase of aqueous pollutants. Different plasma discharge methods are provided and also demonstrated general mechanism for degrading a range of contaminants in wastewater and harmful microorganisms have been presented in this review. This manuscript also presented a holistic overview of the advancement of direct current glow plasma discharge in waste water treatment, which exhibits distinctive features and widely examined as an efficient approach for sterilizing and decontamination. Besides, several parameters including input power, $\mathrm{pH}$ of reactive medium, gas input, temperature and solution conductivity, plasma reactor and electrodes can influence the performance of plasma systems. It has also shown high efficiency in removing various aqueous pollutants and microorganisms including SARS-CoV-2, a deadly and contagious virus in wastewater as compared to other conventional techniques and advanced oxidation processes. But looking ahead, still many obstacles remain to be surmounted for further research and development in cold plasma technology in order to meet commercial use and industrial application.

Acknowledgements This paper has been supported by the RUDN University Strategic Academic Leadership Program.

Author contribution PG worked on writing the detailing of the manuscript. PB and NCJ analysed and interpreted the data collection on wastewater. BB worked on the diagrams and editing of manuscript. VK works on the proof reading of the manuscript. MST studied the working mechanisms of cold plasma technology. BP studied the inactivation mechanism of bacteria, virus. All the authors read and approved the final manuscript.

Data availability Not applicable

\section{Declarations}

Ethics approval Not applicable

Consent to participate Not applicable

Consent for publication Not applicable

Conflict of interest The authors declare no competing interests. 


\section{References}

Abdel-Fattah E (2019) Atmospheric pressure helium plasma jet and its applications to methylene blue degradation. J Electrost 101:103360

Abdul-Majeed WS, Karunakaran E, Biggs CA, Zimmerman WB (2015) Development of wastewater treatment system based on cascade dielectric barrier discharge plasma atomizers. J Environ Sci Health A 50(12):1249-1258

Abia D, Nzali S, Acayanka E, Kamgang GY, Laminsi S, Ghogomu PM (2015) Synergetic effect of gliding arc discharge treatment and biosorption for removal of nitrophene and glycine from aqueous solution. J Ind Eng Chem 29:156-162

Ajo P, Preis S, Vornamo T, Mänttäri M, Kallioinen M, Louhi-Kultanen M (2018) Hospital wastewater treatment with pilot-scale pulsed corona discharge for removal of pharmaceutical residues. J Environ Chem Eng 6(2):1569-1577

Ali W, Zhang H, Wang Z, Chang C, Javed A, Ali K, Du W, Khan N, Niazi NK, Mao K, Yang Z (2021) Occurrence of various viruses and recent evidence of SARS-CoV-2 in wastewater systems. J Hazard Mater 414:125439

Ameta, S. C., \& Ameta, R. (Eds.). (2018). Advanced oxidation processes for wastewater treatment: emerging green chemical technology. Academic press.

Amoah ID, Kumari S, Bux F (2020) Coronaviruses in wastewater processes: Source, fate and potential risks. Environ Int 143:105962

Amoatey P, Bani R (2011) Wastewater management. INTECH Open Access Publisher

Bakheet B, Islam MA, Beardall J, Zhang X, McCarthy D (2018) Electrochemical inactivation of Cylindrospermopsis raciborskii and removal of the cyanotoxin cylindrospermopsin. J Hazard Mater 344:241-248

Bhatnagar P (2019) Cold Plasma Technology: A New Hope to Food Industry. Octa Jf Biosci 7:108-112

Bisht B, Bhatnagar P, Gururani P, Kumar V, Tomar MS, Sinhmar R, Kumar S (2021) Food irradiation: Effect of ionizing and nonionizing radiations on preservation of fruits and vegetables-a review. Trends Food Sci Technol 114:372-385

Boretti A, Rosa L (2019) Reassessing the projections of the world water development report. NPJ Clean Water 2(1):1-6

Chandana L, Reddy PMK, Subrahmanyam C (2015) Atmospheric pressure non-thermal plasma jet for the degradation of methylene blue in aqueous medium. Chem Eng J 282:116-122

Chandana L, Sangeetha CJ, Shashidhar T, Subrahmanyam C (2018)Nonthermal atmospheric pressure plasma jet for the bacterial inactivation in an aqueous medium. Sci Total Environ 640:493-500

Chen Y, Chen L, Deng Q, Zhang G, Wu K, Ni L, Cheng Z (2020) The presence of SARS-CoV-2 RNA in the feces of COVID-19 patients. J Med Virol 92(7):833-840

Connors KA, Dyer SD, Belanger SE (2017) Advancing the quality of environmental microplastic research. Environ Toxicol Chem 36(7): $1697-1703$

Crini G, Lichtfouse E (2019) Advantages and disadvantages of techniques used for wastewater treatment. Environ Chem Lett 17(1): $145-155$

Dojčinović BP, Roglić GM, Obradović BM, Kuraica MM, Kostić MM, Nešić J, Manojlović DD (2011) Decolorization of reactive textile dyes using water falling film dielectric barrier discharge. J Hazard Mater 192(2):763-771

Duan L, Li J, Shang K, Na L, Wu Y (2015) Enhanced biodegradability of coking wastewater by gas phase dielectric barrier discharge plasma. Sep Purif Technol 154:359-365

Edokpayi JN, Enitan-Folami AM, Adeeyo AO, Durowoju OS, Jegede AO, \& Odiyo JO (2020) Recent trends and national policies for water provision and wastewater treatment in South Africa. In
Water Conservation and Wastewater Treatment in BRICS Nations (pp. 187-211). Elsevier.

Edokpayi JN, Odiyo JO, Popoola OE, Msagati TA (2021) Evaluation of contaminants removal by waste stabilization ponds: A case study of Siloam WSPs in Vhembe District, South Africa. Heliyon 7(2): e06207

Ehlbeck J, Schnabel U, Polak M, Winter J, Von Woedtke T, Brandenburg R, Weltmann KD (2010) Low temperature atmospheric pressure plasma sources for microbial decontamination. J Phys D Appl Phys 44(1):013002

Ekanayake UM, Barclay M, Seo DH, Park MJ, MacLeod J, O'Mullane AP, Ostrikov KK (2021) Utilization of plasma in water desalination and purification. Desalination 500:114903

Ekezie FGC, Sun DW, Cheng JH (2017) A review on recent advances in cold plasma technology for the food industry: Current applications and future trends. Trends Food Sci Technol 69:46-58

Fatima N, Kumar V (2020) Microalgae based hybrid approach for bioenergy generation and bioremediation: a review. Octa J Biosci 8(2):113-123

Filipić A, Gutierrez-Aguirre I, Primc G, Mozetič M, Dobnik D (2020) Cold plasma, a new hope in the field of virus inactivation. Trends Biotechnol 38(11):1278-1291

García MC, Mora M, Esquivel D, Foster JE, Rodero A, JiménezSanchidrián C, Romero-Salguero FJ (2017) Microwave atmospheric pressure plasma jets for wastewater treatment: degradation of methylene blue as a model dye. Chemosphere 180:239-246

Garcia-Segura S, Lanzarini-Lopes M, Hristovski K, Westerhoff P (2018) Electrocatalytic reduction of nitrate: Fundamentals to full-scale water treatment applications. Appl Catal B Environ 236:546-568

Gavahian M, Chu YH, Jo C (2019) Prospective applications of cold plasma for processing poultry products: Benefits, effects on quality attributes, and limitations. Compr Rev Food Sci Food Saf 18(4): 1292-1309

Ghezzar MR, Abdelmalek F, Belhadj M, Benderdouche N, Addou A (2009) Enhancement of the bleaching and degradation of textile wastewaters by gliding arc discharge plasma in the presence of TiO2 catalyst. J Hazard Mater 164(2-3):1266-1274

Guo J, Huang K, Wang J (2015) Bactericidal effect of various nonthermal plasma agents and the influence of experimental conditions in microbial inactivation: A review. Food Control 50:482-490

Guo L, Xu R, Gou L, Liu Z, Zhao Y, Liu D, Kong MG (2018) Mechanism of virus inactivation by cold atmospheric-pressure plasma and plasma-activated water. Appl Environ Microbiol 84(17)

Guo L, Yao Z, Yang L, Zhang H, Qi Y, Gou L, Kong MG (2020)Plasmaactivated water: An alternative disinfectant for $\mathrm{S}$ protein inactivation to prevent SARS-CoV-2 infection. Chem Eng J 421(Part 2): 127742

Hoffmann C, Berganza C, Zhang J (2013) Cold Atmospheric Plasma: methods of production and application in dentistry and oncology. Med Gas Res 3(1):1-15

Hong YC, Ma SH, Kim K, Shin YW (2019) Multihole dielectric barrier discharge with asymmetric electrode arrangement in water and application to sterilization of aqua pathogens. Chem Eng J 374:133-143

Hossain MZ (2015) Water: the most precious resource of our life. Global J Adv Res 2(9):1-11

Iervolino G, Vaiano V, Palma V (2019) Enhanced removal of water pollutants by dielectric barrier discharge non-thermal plasma reactor. Sep Purif Technol 215:155-162

Jiang B, Zheng J, Liu Q, Wu M (2012) Degradation of azo dye using nonthermal plasma advanced oxidation process in a circulatory airtight reactor system. Chem Eng J 204:32-39

Jiang B, Zheng J, Qiu S, Wu M, Zhang Q, Yan Z, Xue Q (2014) Review on electrical discharge plasma technology for wastewater remediation. Chem Eng J 236:348-368 
Kim HS, Lee DH, Fridman A, Cho YI (2014) Residual effects and energy cost of gliding arc discharge treatment on the inactivation of Escherichia coli in water. Int J Heat Mass Transf 77:1075-1083

Kim KS, Yang CS, Mok YS (2013) Degradation of veterinary antibiotics by dielectric barrier discharge plasma. Chem Eng J 219:19-27

Krishna S, Maslani A, Izdebski T, Horakova M, Klementova S, Spatenka P (2016) Degradation of Verapamil hydrochloride in Water by gliding arc discharge. Chemosphere 152:47-54

Laureano-Anzaldo CM, González-López ME, Pérez-Fonseca AA, CruzBarba LE, Robledo-Ortíz JR (2020)Plasma-enhanced modification of polysaccharides for wastewater treatment: A review. Carbohydr Polym 252:117195

Lee C, Kim J, Yoon J (2011) Inactivation of MS2 bacteriophage by streamer corona discharge in water. Chemosphere 82(8):1135-1140

Li S, Dang X, Yu X, Abbas G, Zhang Q, Cao L (2020) The application of dielectric barrier discharge non-thermal plasma in VOCs abatement: A review. Chem Eng J 388:124275

Liu J, Hernández SE, Swift S, Singhal N (2018a) Estrogenic activity of cylindrospermopsin and anatoxin-a and their oxidative products by FeIII-B*/H2O2. Water Res 132:309-319

Liu M, Preis S, Kornev I, Hu Y, Wei CH (2018b) Pulsed corona discharge for improving treatability of coking wastewater. J Environ Sci 64:306-316

Lodder W, de Roda Husman AM (2020)SARS-CoV-2 in wastewater: potential health risk, but also data source. Lancet Gastroenterol Hepatol 5(6):533-534

Lu H, Patil S, Keener KM, Cullen PJ, Bourke P (2014) Bacterial inactivation by high-voltage atmospheric cold plasma: influence of process parameters and effects on cell leakage and DNA. J Appl Microbiol 116(4):784-794

Lunov O, Zablotskii V, Churpita O, Jäger A, Polívka L, Syková E, Kubinová S̆ (2016) The interplay between biological and physical scenarios of bacterial death induced by non-thermal plasma. Biomaterials 82:71-83

Ma S, Kim K, Chun S, Moon SY, Hong Y (2020)Plasma-assisted advanced oxidation process by a multi-hole dielectric barrier discharge in water and its application to wastewater treatment. Chemosphere 243:125377

Magureanu M, Bradu C, Parvulescu VI (2018) Plasma processes for the treatment of water contaminated with harmful organic compounds. J Phys D Appl Phys 51(31):313002

Mir SA, Siddiqui MW, Dar BN, Shah MA, Wani MH, Roohinejad S, Annor GA, Mallikarjunan K, Chin CF, Ali A (2020) Promising applications of cold plasma for microbial safety, chemical decontamination and quality enhancement in fruits. J Appl Microbiol 129(3):474-485

Mishra R, Bhatia S, Pal R, Visen A, Trivedi H (2016) Cold plasma: emerging as the new standard in food safety. Research Inventy: Int J Eng Sci 6:15-20

Misra NN, Jo C (2017) Applications of cold plasma technology for microbiological safety in meat industry. Trends Food Sci Technol 64:74-86

Misra NN, Yadav B, Roopesh MS, Jo C (2019) Cold plasma for effective fungal and mycotoxin control in foods: mechanisms, inactivation effects, and applications. Compr Rev Food Sci Food Saf 18(1): 106-120

Murugesan P, Moses JA, Anandharamakrishnan C (2020) Performance of an atmospheric plasma discharge reactor for inactivation of Enterocococcus faecalis and Escherichia coli in aqueous media. J Environ Chem Eng 8(4):103891

Nanda M, Kumar V (2021) Implications of bacterial multi-metal tolerance for mitigation of heavy metal pollutants from wastewater. Octa Jf Biosci 9(1):37-44

Nasir A, Caetano-Anollés G (2015) A phylogenomic data-driven exploration of viral origins and evolution. Sci Adv 1(8):e1500527
National inventory of sewage treatment plants CPCB, $2021 \mathrm{https} / / \mathrm{cpcb}$. nic.in/openpdffile.php?id=UmVwb3J0RmlsZXMvMTIy OF8xNjE1MTk2MzIyX211ZGlhcGhvdG85NTY0LnBkZg==

Nomoto H, Ishikane M, Katagiri D, Kinoshita N, Nagashima M, Sadamasu K, Ohmagari N (2020) Cautious handling of urine from moderate to severe COVID-19 patients. Am J Infect Control 48(8):969-971

Ognier S, Iya-Sou D, Fourmond C, Cavadias S (2009) Analysis of mechanisms at the plasma-liquid interface in a gas-liquid discharge reactor used for treatment of polluted water. Plasma Chem Plasma Process 29(4):261-273

Ojha S, Fröhling A, Durek J, Ehlbeck J, Tiwari BK, Schlüter OK, \& Bußler S (2020) Principles and Application of Cold Plasma in Food Processing, 519-540.

Ott LC, Appleton HJ, Shi H, Keener K, Mellata M (2021) High voltage atmospheric cold plasma treatment inactivates Aspergillus flavus spores and deoxynivalenol toxin. Food Microbiol 95:103669

Oturan, M. A., \& Aaron, J. J. (2014). Advanced oxidation processes in water/wastewater treatment: principles and applications. A review. Crit Rev Environ Sci Technol, 44(23), 2577-2641.

Ozen E, Singh RK (2020) Atmospheric cold plasma treatment of fruit juices: A review. Trends Food Sci Technol 103:144-151

Pandiyaraj KN, Vasu D, Ramkumar MC, Deshmukh RR, Ghobeira R (2021) Improved degradation of textile effluents via the synergetic effects of $\mathrm{Cu}-\mathrm{CeO} 2$ catalysis and non-thermal atmospheric pressure plasma treatment. Sep Purif Technol 258:118037

Patange A, Boehm D, Giltrap M, Lu P, Cullen PJ, Bourke P (2018) Assessment of the disinfection capacity and eco-toxicological impact of atmospheric cold plasma for treatment of food industry effluents. Sci Total Environ 631:298-307

Pricaz M, Uță AC (2015) Gamma Radiation for Improvements in Food Industry, Environmental Quality and Healthcare. Rom J Biophys 25(2):143-162

Rashmei Z, Bornasi H, Ghoranneviss M (2016) Evaluation of treatment and disinfection of water using cold atmospheric plasma. J Water Health 14(4):609-616

Reddy PMK, Subrahmanyam C (2012) Green Approach for Wastewater Treatment Degradation and Mineralization of Aqueous Organic Pollutants by Discharge Plasma. Ind Eng Chem Res 51(34): 11097-11103

Reynamartínez R, Céspedes RN, Alonso MI, Acosta YR (2018) Use of cold plasma technology in biomaterials and their potential utilization in controlled administration of active substances. J Mater Sci 4(5): 555649

Rimoldi SG, Stefani F, Gigantiello A, Polesello S, Comandatore F, Mileto D, Salerno F (2020) Presence and infectivity of SARSCoV-2 virus in wastewaters and rivers. Sci Total Environ 744: 140911

Saeid S, Tolvanen P, Kumar N, Eränen K, Peltonen J, Peurla M, Salmi T (2018) Advanced oxidation process for the removal of ibuprofen from aqueous solution: a non-catalytic and catalytic ozonation study in a semi-batch reactor. Appl Catal B Environ 230:77-90

Saïm N, Ghezzar MR, Guyon C, Abdelmalek F, Tatoulian M, Addou A (2015) New prototype for the treatment of falling film liquid effluents by gliding arc discharge part II: Plasmacatalytic activity of TiO2 thin film deposited by magnetron sputterin. Chem Eng Process Process Intensif 98:32-40

Schneider M, Rataj R, Kolb JF, Bláha L (2020) Cylindrospermopsin is effectively degraded in water by pulsed corona-like and dielectric barrier discharges. Environ Pollut 266:115423

Scholtz V, Pazlarova J, Souskova H, Khun J, Julak J (2015) Nonthermal plasma-A tool for decontamination and disinfection. Biotechnol Adv 33(6):1108-1119

Shah AI, Dar MUD, Bhat RA, Singh JP, Singh K, Bhat SA (2020) Prospectives and challenges of wastewater treatment technologies 
to combat contaminants of emerging concerns. Ecol Eng 152: 105882

Sharma, R. R., Reddy, S. V. R., \& Sethi, S. (2018). Cold Plasma Technology for Surface Disinfection of Fruits and Vegetables. In Postharvest Disinfection of Fruits and Vegetables (pp. 197-209). Academic Press.

Shimizu K, Kristof J, \& Blajan MG (2018) Applications of Dielectric Barrier Discharge Microplasma. In Atmospheric Pressure Plasmafrom Diagnostics to Applications. IntechOpen.

Shrestha S, Shrestha S, Shindo J, Sherchand JB, Haramoto E (2018) Virological quality of irrigation water sources and pepper mild mottle virus and tobacco mosaic virus as index of pathogenic virus contamination level. Food Environ Virology 10(1):107-120

Slamani S, Abdelmalek F, Ghezzar MR, Addou A (2018) Initiation of Fenton process by plasma gliding arc discharge for the degradation of paracetamol in water. J Photochem Photobiol A Chem 359:1-10

Svarnas P, Giannakopoulos E, Kalavrouziotis I, Krontiras C, Georga S, Pasolari RS, Chrysochoou D (2020) Sanitary effect of FE-DBD cold plasma in ambient air on sewage biosolids. Sci Total Environ 705: 135940

Thakur AK, Sathyamurthy R, Velraj R, Lynch I, Saidur R, Pandey AK, GaneshKumar P (2021) Secondary transmission of SARS-CoV-2 through wastewater: Concerns and tactics for treatment to effectively control the pandemic. J Environ Manag 290:112668

Taghvaei H, Rahimpour MR (2016) Upgrading of anisole using in situ generated hydrogen in pin to plate pulsed corona discharge. Royal Soc Chem Adv 6(100):98369-98380

Thirumdas R, Sarangapani C, Annapure US (2015) Cold plasma: a novel non-thermal technology for food processing. Food Biophysics 10(1):1-11

Tichonovas M, Krugly E, Racys V, Hippler R, Kauneliene V, Stasiulaitiene I, Martuzevicius D (2013) Degradation of various textile dyes as wastewater pollutants under dielectric barrier discharge plasma treatment. Chem Eng J 229:9-19

Tiya-Djowe A, Acayanka E, Lontio-Nkouongfo G, Laminsi S, Gaigneaux EM (2015) Enhanced discolouration of methyl violet $10 \mathrm{~B}$ in a gliding arc plasma reactor by the maghemite nanoparticles used as heterogeneous catalyst. J Environ Chem Eng 3(2):953-960

Vaiano V, Iervolino G (2018) Facile method to immobilize ZnO particles on glass spheres for the photocatalytic treatment of tannery wastewater. J Colloid Interface Sci 518:192-199

Vaiano V, Iervolino G, Rizzo L, Sannino D (2017) Advanced oxidation processes for the removal of food dyes in wastewater. Curr Org Chem 21(12):1068-1073

Van Doremalen N, Bushmaker T, Morris DH, Holbrook MG, Gamble A, Williamson BN et al Surface Stability of SARS-CoV-2 as Compared with SARS-CoV-1. N Engl J Med 382:16

Van Nguyen D, Ho NM, Hoang KD, Le TV, Le VH (2020) An investigation on treatment of groundwater with cold plasma for domestic water supply. Groundw Sustain Dev 10:100309

Wang C, Qu G, Wang T, Deng F, Liang D (2018) Removal of tetracycline antibiotics from wastewater by pulsed corona discharge plasma coupled with natural soil particles. Chem Eng J 346:159-170

Wang D, Hu B, Hu C, Zhu F, Liu X, Zhang J, Peng Z (2020a) Clinical characteristics of 138 hospitalized patients with 2019 novel coronavirus-infected pneumonia in Wuhan, China. Jama 323(11): 1061-1069

Wang J, Sun Y, Feng J, Xin L, Ma J (2016) Degradation of triclocarban in water by dielectric barrier discharge plasma combined with $\mathrm{TiO} 2 /$ activated carbon fibers: effect of operating parameters and byproducts identification. Chem Eng J 300:36-46
Wang N, Chen DZ, Zou LS (2015) Influence of non-thermal plasma pretreatment on the scaling characteristics of viscous oil wastewater during evaporation. Appl Therm Eng 75:779-788

Wang Q, Wang T, Qu G, Zhang Y, Sun Q, Guo X, Jia H (2020b)Highefficient removal of tetrabromobisphenol $\mathrm{A}$ in aqueous by dielectric barrier discharge: Performance and degradation pathways. Sep Purif Technol 240:116615

Wang X, Huang Q, Ding S, Liu W, Mei J, Luo J, He F (2020c) Micro hollow cathode excited dielectric barrier discharge (DBD) plasma bubble and the application in organic wastewater treatment. Sep Purif Technol 240:116659

Whitehead JC (2016) Plasma-catalysis: the known knowns, the known unknowns and the unknown unknowns. J Phys D Appl Phys 49(24): 243001

World Health Organization, 2019 https:/www.who.int/news-room/factsheets/detail/drinking-water

Wu H, Fan J, Chen W, Yang C (2020) Dielectric barrier dischargecoupled Fe-based zeolite to remove ammonia nitrogen and phenol pollutants from water. Sep Purif Technol 243:116344

Xu H, Ma R, Zhu Y, Du M, Zhang H, Jiao Z (2020) A systematic study of the antimicrobial mechanisms of cold atmospheric-pressure plasma for water disinfection. Sci Total Environ 703:134965

Xu H, Zhu Y, Du M, Wang Y, Ju S, Ma R, Jiao Z (2021) Subcellular mechanism of microbial inactivation during water disinfection by cold atmospheric-pressure plasma. Water Res 188:116513

Xu Z, Cheng C, Shen J, Lan Y, Hu S, Han W, Chu PK (2018) In vitro antimicrobial effects and mechanisms of direct current air-liquid discharge plasma on planktonic Staphylococcus aureus and Escherichia coli in liquids. Bioelectrochemistry 121:125-134

Yan H, Lu P, Pan Z, Wang X, Zhang Q, Li L (2013)Ce/SBA-15 as a heterogeneous ozonation catalyst for efficient mineralization of dimethyl phthalate. J Mol Catal A Chem 377:57-64

Yan Y, Shin WI, Pang YX, Meng Y, Lai J, You C, Zhao H, Lester E, Wu T, Pang CH (2020) The first 75 days of novel coronavirus (SARSCoV-2) outbreak: recent advances, prevention, and treatment. Int J Environ Res Public Health 17(7):2323

Yeo C, Kaushal S, Yeo D (2020) Enteric involvement of coronaviruses: is faecal-oral transmission of SARS-CoV-2 possible? Lancet Gastroenterol Hepatol 5(4):335-337

Yong HI, Kim HJ, Park S, Alahakoon AU, Kim K, Choe W, Jo C (2015) Evaluation of pathogen inactivation on sliced cheese induced by encapsulated atmospheric pressure dielectric barrier discharge plasma. Food Microbiol 46:46-50

Zainal MNF, Redzuan N, Misnal MFI (2015) Brief review: Cold plasma. Jurnal Teknologi 74(10)

Zeghioud H, Nguyen-Tri P, Khezami L, Amrane A, Assadi AA (2020) Review on discharge Plasma for water treatment: mechanism, reactor geometries, active species and combined processes. J Water Process Eng 38:101664

Zhang C, Fang Z, Liu W, Tian F, Bai M (2016) Rapid removal of bacterial endotoxin and natural organic matter in water by dielectric barrier discharge plasma: efficiency and toxicity assessment. J Hazard Mater 318:15-23

Zhang G, He X, Nadagouda MN, O'Shea KE, Dionysiou DD (2015) The effect of basic $\mathrm{pH}$ and carbonate ion on the mechanism of photocatalytic destruction of cylindrospermopsin. Water Res 73:353-361

Zhang S (2015)Atmospheric pressure RF plasma jet: characterization of flow and $\mathrm{O} 2$ chemistry. Eindhoven, Netherlands: Technische Universiteit Eindhoven.

Publisher's note Springer Nature remains neutral with regard to jurisdictional claims in published maps and institutional affiliations. 